\title{
THE FIELD OF RECENT TECTONIC STRESSES IN CENTRAL AND SOUTH-EASTERN ASIA
}

\author{
Yu. L. Rebetsky ${ }^{1}$, R. S. Alekseev ${ }^{1,2}$ \\ ${ }^{1}$ Schmidt Institute of the Physics of the Earth RAS, Moscow, Russia \\ ${ }^{2}$ Moscow State University, Moscow, Russia
}

\begin{abstract}
The publication presents results of the study aimed at reconstruction of recent crustal stresses for Central and SouthEastern Asia with application of the method of cataclastic analysis of displacements caused by ruptures, which was proposed by Yu.L. Rebetsky. Two sources of seismic data were referred to: (1) the catalog comprising data from publications covering the period from 1904 to 1992, and (2) the Global Centroid Moment Tensor (CMT) Database of earthquake mechanisms (http://earthquake.usgs.gov/eqarchives/sopor), which covers the period from 1978 to 2010. The method of cataclastic analysis in its earliest version was applied in 1996 and 1997 when seismic data from the first catalog were analyzed, and it yielded only parameters of stress ellipsoids; the reconstructions were published in a Russian-Chinese journal (it does not exist now). In this paper, these reconstructions are presented in new graphical formats of GIS. Data from the Global CMT Database were analyzed by the method of cataclastic analysis in the new revision with application of its stages 1 and 2 . Based on the calculations, orientations of axes of principal stresses, types of ellipsoids, correlations between spherical and deviatoric components of stress tensors, and reduced stresses were determined. The two sets of reconstructions are compared in this paper. The catalog of earthquake focal mechanisms for the period from 1904 to 1992 consolidated information provided by different authors, and thus focal data for many seismic events were highly inconsistent; therefore, the reliability of reconstructions based on such data seems to be lower than that on the basis the Global CMT Database for the period from 1978 to 2010. Some of the reconstructed stress tensor parameters are mapped. For the areas which data are given in the Global CMT Database and considered as more reliable, mapping is based on stress parameters calculated from such data. For the areas that are not covered by the Global CMT Database, reconstructions based on the first catalog are mapped. In the maps showing consolidated patterns of the state of stresses, spacious areas of horizontal extension of the crust in Tibet are clearly identified. In the south, such areas are bordered by regions of horizontal compression of the crust in Himalaya; in the north and north-east, they are bordered by regions of horizontal shear of the crust in East Kunlun. According to results of calculations at stage 2 of the method of cataclastic analyses, the crust in the central part of Tibet is subject to intensive confining pressure and lateral compression that is reduced in the neighboring regions. The crust in the southern and northern parts of Pamir is also subject to horizontal extension and shear. Regions of horizontal compression are located to the north, west and south of Pamir. Regulations of the field of recent tectonic stresses of Tibet and Pamir, which are revealed in this study, can be explained by the concept of 'tectonic spreading' of these regions due to gravity, which causes intensive horizontal spreading of the crust in Himalaya when the southern boundary of Tibet bends outwards and spreads over the Indian 'indenter' moving in the north-northeastern direction. It is suggested by the data on horizontal extension of the crust in Tibet and underthrusting shear stresses over the horizontal zones that the impact Indian 'indenter' does not go beyond the crust of Pamir and the crust of the central parts of Tibet which is located above the long-term active mantle plume.
\end{abstract}

Key words: tension, mechanisms of seismic focus, cataclastic flow, frail strength, destruction, geodynamic mode, crust deformation mechanism.

Recommended by V.A. San'kov

Citation: Rebetsky Yu.L., Alekseev R.S. 2014. The field of recent tectonic stresses in Central and South-Eastern Asia. Geodynamics \& Tectonophysics 5 (1), 257-290. doi:10.5800/GT-2014-5-1-0127. 


\title{
ПОЛЕ СОВРЕМЕННЫХ ТЕКТОНИЧЕСКИХ НАПРЯЖЕНИЙ СРЕДНЕЙ И ЮГО-ВОСТОЧНОЙ АЗИИ
}

\author{
Ю. Л. Ребецкий ${ }^{1}$, Р. С. Алексеев ${ }^{1,2}$ \\ ${ }^{1}$ Институт физики Земли им. О.Ю. Шмидта РАН, Москва, Россия \\ ${ }^{2}$ Московский государственный университет, Москва, Россия
}

\begin{abstract}
Аннотация: В работе представлены результаты реконструкции современных напряжений в коре Средней и ЮгоВосточной Азии при использовании метода катакластического анализа разрывных смещений Ю.Л. Ребецкого. Основой реконструкции напряжений служили два различных каталога. Первый являлся сборным, созданным из разнородных сейсмологических данных, полученных разными авторами за период наблюдений 1904-1992 гг., а второй каталог механизмов Global CMT (http://earthquake.usgs.gov/eqarchives/sopor) 1978-2010 гг. Реконструкция по сейсмологическим данным первого каталога выполнялась в 1996-1997 гг. по самой ранней модификации метода катакластического анализа, позволявшей получать только параметры эллипсоида напряжений. Результаты этой реконструкции были опубликованы в российско-китайском журнале, который уже не издается. В настоящей работе эти результаты представлены в новых графических формах, выполненных в ГИС. Реконструкция по данным второго каталога выполнялась по современной версии метода катакластического анализа с использованием процедур первого и второго его этапов. Таким образом, в этих расчетах были получены данные не только об ориентации осей главных напряжений и о виде его эллипсоида, но и о соотношении шаровой и девиаторной компонент тензора напряжений, а также о редуцированных напряжениях. В работе делается сравнительный анализ обеих реконструкций. Поскольку каталог механизмов очагов землетрясений первого расчета за 1904-1992 гг. содержал большое число событий с существенно отличающимися данными об очагах, полученными разными авторами, достоверность результатов этой реконструкции представляется меньшей, чем по данным каталога Global CMT за 1978-2010 гг. В работе построены суммарные карты некоторых параметров тензора напряжений по данным обеих реконструкций. При этом в тех областях, где были получены данные о напряжениях по каталогу Global CMT, эти данные считались более надежными, и именно их параметры здесь приводились. Результаты реконструкции первого сборного каталога показаны там, где не было данных по результатам расчета второго каталога. Суммарные карты напряженного состояния выявили наличие обширных областей горизонтального растяжения в коре Тибета, которые с юга ограничены областями горизонтального сжатия коры Гималаев, а с севера и северо-востока - областями горизонтального сдвига коры Восточного Куньлуня. Расчеты второго этапа метода катакластического анализа показали, что в центральной части коры Тибета наблюдается интенсивное эффективное давление и латеральное сжатие, которое ослабевает в областях его окружения. Южная и северная части коры Памира также испытывают соответственно состояние горизонтального растяжения и сдвига. С севера, запада и юга кора Памира окружена областями горизонтального сжатия. Выявленные закономерности поля современных напряжений Тибета и Памира находят свое объяснение в явлении тектонического «растекания» этих областей под собственным весом, что создает обстановку интенсивного горизонтального расплющивания коры Гималаев при выгибе южной границы Тибета, «набегающей» на двигающийся на север - северо-восток Индийский индентор. Данные о горизонтальном растяжении в коре Тибета вместе с поддвиговыми касательными напряжениями на горизонтальных площадках показывают, что влияние Индийского индентора не распространяется далее коры Памира и центральных областей коры Тибета, которая располагается над длительно действующим мантийным плюмом.
\end{abstract}

Ключевые слова: напряжения, механизмы очагов землетрясения, катакластическое течение, хрупкая прочность, разрушение, геодинамический режим, механизм деформирования коры.

\section{1. ВВЕДЕНИЕ}

В изучении природных напряжений, действующих в земной коре сейсмоактивных областей, в последние годы наметился существенный прогресс, так как получили развитие подходы не только по расчету ориентации главных осей тензора напряжений, но и по оценке величин напряжений [Angelier, 1989; Michael, 1984; Hardebeck, Hauksson, 2001; Rebetsky, 1994, 2003, 2005]. В ИФЗ РАН во второй половине 90-х годов прошлого века получил развитие метод катакластического анализа разрывных смещений (MKA) [Rebetsky, 1996,
1997, 1999], в рамках которого переход от параметров эллипсоида напряжений (ориентация осей главных напряжений и значение коэффициента Лоде-Надаи) к соотношению шаровой и девиаторных компонент тензора напряжений (второй этап МКА) делается на основе обобщения результатов экспериментов по разрушению образцов горных пород [Byerlee, 1968, 1978; Brace, 1978]. Подобное обобщение определяет попадание на диаграмме Мора напряженных состояний на плоскостях хрупких трещин (реализованная нодальная плоскость в механизме очага землетрясения) в полосу разрушения [Rebetsky, 2007a]. 


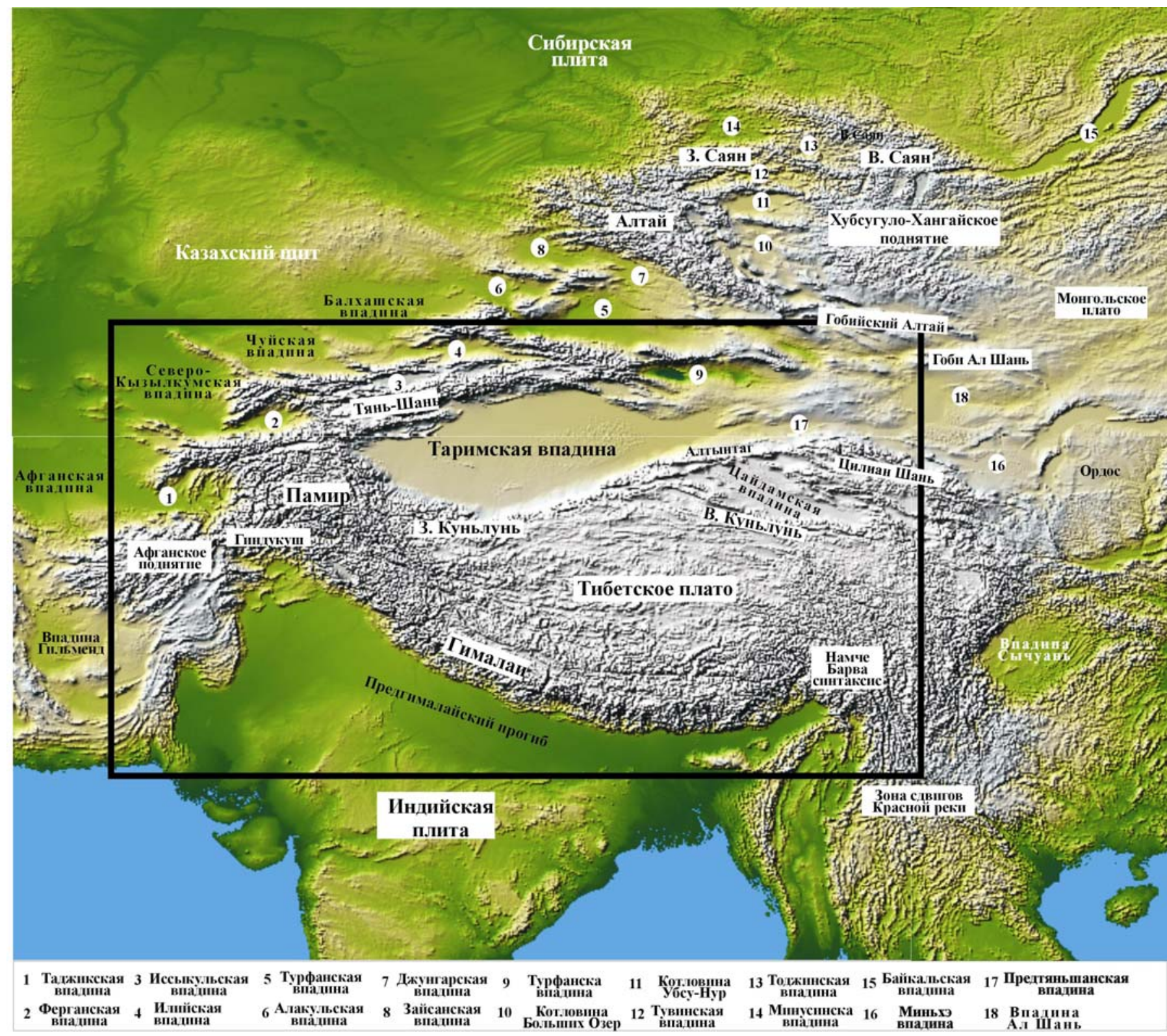

Рис. 1. Топография территории Высокой Азии и примыкающей к ней территории - области реконструкции напряжений в работе [Rebetsky et al., 1997].

Название тектонических провинций по работам [Stuwe, 2007; Kunin et al., 1988; Burtman, 2012; Levi, Sherman, 2005; Laverov et al., 2006]. Прямоугольником выделена область, для которой в настоящей работе выполнялась новая реконструкция напряжений.

Fig. 1. Topography of High Asia and neighbouring territories for which stresses were reconstructed in [Rebetsky et al., 1997].

Tectonic names correspond to those in [Stuwe, 2007; Kunin et al., 1988; Burtman, 2012; Levi, Sherman, 2005; Laverov et al., 2006]. The box shows the area which new stress reconstructions are presented in this study.

Если данные об ориентации осей главных напряжений можно использовать для выявления типов геодинамических режимов исследуемых областей [Gushchenko, 1996], то данные о шаровой и девиаторной компонентах тензора напряжений уже позволяют выполнять тектонофизическое районирование земной коры с целью выделения участков коры различной степени опасности формирования сильного землетрясения [Rebetsky, 2007a, 2007b, 2007c, 2007d, 2007e].
Эти данные расширяют возможности в понимании генезиса напряжений в коре исследуемых территорий, а также могут являться ключевыми в построении геодинамических моделей развития этих областей.

В настоящей работе будут представлены результаты реконструкции напряженного состояния для коры Средней и Юго-Восточной Азии (рис. 1), выполненные MKА в разное время. Первая реконструкция осуществлялась в середине 90-х годов прошлого века [Re- 
betsky et al., 1997], когда программный алгоритм MКА только разрабатывался и в большей своей части носил следы своего предшественника - кинематического метода О.И. Гущенко [Gushchenko, 1979]. В то время MКА был одноэтапным и позволял определять только параметры эллипсоида напряжений. Новая реконструкция напряжений этого района выполнялась по современному алгоритму МКА, содержащему четыре этапа расчета напряжений [Rebetsky, 2007a], реализованному в компьютерной программе STRESSseism. Некоторые элементы расчета ранее были опубликованы в материалах конференций [Alekseev, Rebetsky, 2011, 2012]. В настоящей статье мы представим и сравним результаты обеих реконструкций напряженного состояния.

Описание основной части статьи предварим разъяснением используемых в статье тектонофизических терминов. Прежде всего отметим, что термин «реконструкция напряжений» отвечает обратной задаче тектонофизики, в рамках которой по данным о разрывных смещениях разного типа (сейсмологические индикаторы - механизмы очагов землетрясений, геологические индикаторы - зеркала скольжения) определяются параметры напряженного состояния. Эта обратная задача отличается от прямой задачи тектонофизики, в которой данные о напряжениях и деформациях рассчитывают либо прямо измеряют при решении краевой задачи механики или при физическом моделировании.

Тензор напряжений характеризует напряженное состояние в точке среды. В механике часто под термином «тип напряженного состояния» понимается как спектр параметров, определяющих характер тензора напряжений в точке (напряженное состояние чистого сдвига, одноосного сжатия и т.д.), так и особенности деформирования отдельных областей или элементов конструкций (изгибное напряженное состояние, напряженное состояние кручения, напряженное состояние в окрестности включения и т.д.). В тектонофизике особенности параметров напряженного состояния в точке среды, полученные тем или иным способом (прямая или обратная задача тектонофизики), представляют на основе данных об ориентации осей главных напряжений, при этом термин «тип напряженного состояния» здесь применяется совершенно не так, как это делается в механике. В настоящей статье будем использовать термин «геодинамический тип напряженного состояния», который характеризует ориентацию главных осей напряжений в географической системе координат точки, для которой параметры тензора напряжений получены. При этом ключевым элементом разделения на различные геодинамические типы является близость к оси на зенит одной из осей главных напряжений.

Для описания вида эллипсоида напряжений (это понятие в механике эквивалентно виду тензора напряжений) будем использовать коэффициент Лоде - Надаи, значения которого позволяют выделять эллипсоид од- ноосного сжатия и растяжения, а также промежуточный между ними вид эллипсоида чистого сдвига.

Термин «поле напряжений» означает, что в исследуемом участке коры существует набор определений тензора напряжений в различных точках пространства, связанных между собой единым временным периодом. В свете данной работы речь идет о поле современных напряжений.

При анализе напряженного состояния принимается, что $\sigma_{1}$ - алгебраически наибольшее напряжение, $\sigma_{2}-$ промежуточное главное напряжение и $\sigma_{3}$ - алгебраически наименьшее напряжение (максимальное сжатие). В наших работах, так же как в классической механике, принято, что растягивающие напряжения положительны, а сжимающие отрицательны. Это отличается от правила знаков, принятого в горном деле, где положительными являются сжимающие напряжения.

В настоящее время на западе при тектонофизических исследованиях используется правило знаков, применяемое в горном деле. В советской и российской тектонофизике часть исследователей (ИФЗ РАН, МГУ и др.) применяет правило знаков классической механики, а часть (ИЗК СО РАН и др.) - горного дела.

Это, казалось бы, несущественное различие на самом деле имеет определенные последствия. Дело в том, что, приняв за положительные напряжения значения напряжений сжатия, необходимо в дальнейшем и для деформаций выдерживать такое же правило знаков, т.е. полагать деформацию укорочения положительной, а деформацию удлинения отрицательной. В противном случае надо менять определяющую формулу связи напряжений и деформаций в законе Гука. Если принятие сжатия в качестве положительного напряжения не вызывает особых возражений, то принятие укорочения (уменьшения длины) за положительную деформацию явно расходится с нашим житейским опытом и принятыми со школьной скамьи правилами связи алгебраических значений физических параметров. Алгоритм МКА, используемый в наших работах, использует правило знаков, введенное в классической механике.

\section{2. СЕЙСМОЛОГИЧЕСКИЕ ДАННЫЕ И ИСТОРИЯ ВОПРОСА О РЕКОНСТРУКЦИИ НАПРЯЖЕНИЙ СРЕДНЕЙ И ЮГО-ВОСТОЧНОЙ АЗИИ}

Методы тектонофизической реконструкции природных напряжений при расчетах современного напряженного состояния опираются на сейсмологические данные о механизмах очагов землетрясений. С середины 70-х годов прошлого века, когда началось создание этих методов, для реконструкции напряжений обычно использовались региональные каталоги механизмов очагов землетрясений, опубликованные в научной литературе. Данные о механизмах в подобных каталогах обычно получают в приближении очага 
землетрясения в виде двойного диполя на основе анализа знаков первых вступлений продольной волны [Wickens, Hodgson, 1967; Earthquakes in the USSR; Catalogues of Earthquake]. При такой методике определения механизма очага может иметь место несоответствие его характеристик и магнитуды события. Дело в том, что первые вступления продольной волны могут отвечать начальному малому по протяженности разрушающемуся дефекту, параметры которого (положение плоскости смещения) будут сильно отличаться от параметров основного сейсмогенерирующего разрыва, определяющего энергию землетрясения.

В середине 70-х годов прошлого века сейсмологами были заложены методические основы определения механизмов очагов не по данным о знаках первых выступлений продольных волн, а на основе анализа общей волновой картины [Dzievonski, 1977-1996]. В этом подходе используются записи широкополосных цифровых сейсмических станций (см. например [Pavlov, Abubakirov, 2012]). Подобный подход прежде всего позволяет выполнить определение механизма очага землетрясения меньшим числом станций (в некоторых случаях число станций снижается до 2-3). Поскольку такие определения осуществляются по общей волновой картине, эти механизмы будут отвечать фазе сильных движений в очаге, а не начальному этапу, как это имеет место при определении механизмов по данным первых вступлений. Реализация данного метода решения обратной задачи сейсмологии в рамках проекта Harward CMT (с 2004 г. Global CMT) осуществляется Геологической службой США (USGS) по сейсмологическим данным глобальной сейсмической сети IRIS (http://www.iris.edu). Особое значение созданный и постоянно наращиваемый сейсмологический каталог имеет в связи с тем, что он открыт для общего доступа в сети Интернет на серверах Геологической службы США (http://earthquake.usgs.gov/eqarchives/sopor). В настоящее время в подобном ключе осуществляются определения механизмов очагов землетрясений Японским Метеорологическим Агентством (http:/www.fnet. bosai.go.jp), а также Центром данных Института наук о Земле Тайваня (http://bats.earth.edu.tw).

Глобальный сейсмологический каталог, созданный в 1978 г. Геологической службой США, являлся наиболее перспективным для расчета параметров напряженного состояния как с сейсмологических, так и с тектонофизических позиций. Но в начале $80-$ х годов прошлого века, когда только начали создаваться первые программы по реализации кинематического метода (А.О. Мострюков, Обсерватория Борок, и Ю.Л. Ребецкий, ИФЗ РАН), этот каталог был ограничен временным интервалом в 5-10 лет и не позволял только на его основе выполнять реконструкцию напряжений в сейсмоактивных регионах. Кроме того, для отдельных регионов имелись каталоги механизмов, полученные разными авторами в разные, частично пересекающиеся временные интервалы. В связи с этим в те годы при реконструкции напряжений для крупных регионов и мегарегионов приходилось совмещать каталоги различных типов, полученные не только разными авторами, но и на разных принципах решения обратной задачи сейсмологии (по знакам первых вступлений или по общей волновой картине).

При подобном совмещении в суммируемом каталоге появлялись землетрясения с несколькими вариантами механизмов. Сопоставляя данные о механизмах очагов землетрясений средней силы $\left(M_{b}=4.5-6.5\right)$ региональных сетей, определяемых, как правило, по знакам первых вступлений продольных волн, с данными о механизмах этих же землетрясений, полученными в рамках проекта Global CMT (Harward CMT), можно найти немало примеров их несовпадения. В качестве одного из примеров подобных разночтений можно привести землетрясение 1979 г. с $M_{b}=5.8$, произошедшее в земной коре камчатского сектора северо-западного участка Тихоокеанской сейсмофокальной области (таблица). Для этого землетрясения имеются данные о механизме очага из каталога проекта Harward CMT (Dze) и три разных механизма очага из каталогов, публиковавшихся в журнале «Землетрясения в СССР» [1979] (ССС). Другой пример - это землетрясение на севере Пакистана с $M_{b}=5.7$, также произошедшее в 1979 г. Здесь существовало три варианта определения механизма очага. Одно - из данных Harward CMT (Hrw), одно - опубликованное в [Землетрясения в СССР, 1979] (ССС) и одно - рассчитанное А.О. Мострюковым [Mostryukov, Petrov, 1994] (Mostr). Как видно из таблицы и рис. 2, разные варианты механизмов этих землетрясений могут достаточно сильно отличаться друг от друга.

Подобные различия в механизмах одних и тех же землетрясений приводили к необходимости их учета при реконструкции напряжений, что отражалось в алгоритмах расчета ориентации главных осей напряжений [Gushchenko et al., 1990, 1991; Petrov et al., 1994]. В рамках алгоритма кинематического метода О.И. Гущенко для землетрясений, которые имели несколько вариантов механизмов, область возможного положения оси максимального сжатия $\sigma_{3}$ представляла собой сумму квадрантов, содержащих оси $P$ (максимальное сжатие снимаемых напряжений) этих механизмов [Gushchenko et al., 1991, 1994a, 1994b]. То же самое необходимо было предусмотреть и при определении возможного положения оси $\sigma_{1}$. Поскольку основу кинематического метода составляет нахождение взаимного пересечения квадрантов сжатия и растяжения, содержащих соответственно оси $P$ и $T$ (максимальное растяжение снимаемых напряжений), подобная модификация алгоритма расчета приводила к необходимости привлечения большего числа данных о механизмах очагов землетрясений для расчета главных осей одного стресс-состояния, чем в случаях, когда механизмы очагов определены однозначно. Следствием подобной необходимости являлось и большее усреднение на- 
Yu.L. Rebetsky, R.S. Alekseev: The field of recent tectonic stresses...

Механизм очагов двух землетрясений из многовариантного каталога

Mechanism of the centers of two earthquakes from the multiple catalog

\begin{tabular}{|c|c|c|c|c|c|c|c|c|c|}
\hline Номер & Bap. & Дата & Время & Долг. & Шир. & Глуб. & $\mathrm{P}$ & $\mathrm{T}$ & Ист. \\
\hline \multirow[t]{4}{*}{8355} & 4 & 79.05 .23 & 00.40 .43 & 159.90 & 50.10 & 50 & $108 / 77$ & $312 / 12$ & Hrw 258 \\
\hline & & & & & & & $160 / 70$ & $261 / 04$ & CCC 16 \\
\hline & & & & & & & $357 / 40$ & $194 / 51$ & ССC 41 \\
\hline & & & & & & & $006 / 44$ & $209 / 44$ & CCC 42 \\
\hline \multirow[t]{3}{*}{8501} & 4 & 79.06 .26 & 03.04 .51 & 71.20 & 36.60 & 230 & $15 / 78$ & $188 / 12$ & Hrw 24 \\
\hline & & & & & & & $22 / 10$ & $265 / 70$ & CСС 96 \\
\hline & & & & & & & $194 / 08$ & $312 / 73$ & Mostr 380 \\
\hline
\end{tabular}

П р и м е ч а н и е. В колонках для Р и Т показаны азимуты и углы погружения осей.

$\mathrm{N}$ o t e. Azimuths and plunge angles of axles are shown in the columns $\mathrm{P}$ and $\mathrm{T}$.

пряжений как в пространстве, так и по времени.

Именно в таких условиях в середине 90-х годов прошлого века была выполнена реконструкция природных напряжений по данным о механизмах очагов землетрясений для мегарегиона Юго-Восточной Азии и Океании [Rebetsky et al., 1997]. Для реконструкции использовался МКА, который в тот момент времени не очень сильно отличался от кинематического метода О.И. Гущенко [Gushchenko, 1975]. Собранный для расчета напряжений каталог механизмов очагов землетрясений состоял из 15 региональных каталогов, дополненных глобальным каталогом сейсмологической обсерватории Гарвардского университета. Для участка коры Средней и Юго-Восточной Азии этот каталог насчитывал данные для более 9000 событий для периода времени с 1904 по 1994 г. при магнитудах $M_{b}>4$.

Все данные каталога прошли предварительное тестирование и выверку, что позволило исправить большое количество ошибок как систематического, так и случайного характера. Реконструкция по данным этого каталога механизмов осуществлялась с усреднением по времени > 50 лет, по латеральному расстоянию 100-200 км, по глубине 40 км [Gushchenko et al., 1993, $1994 a, 1994 b]$.

Первая реконструкция напряжений для коры ЮгоВосточной Азии, выполненная в рамках кинематического метода О.И. Гущенко, была представлена в работах [Petrov et al., 1994, 2008]. Некоторое отличие результатов в сравнении с работой [Rebetsky et al., 1997] было вызвано не столько различием методик реконструкции, сколько определенными расхождениями исходных сейсмологических данных о механизмах очагов землетрясений. В работе [Petrov et al., 1994] в качестве основного каталога механизмов использовался авторский каталог, созданный А.О. Мострюковым [Mostryukov, Petrov, 1994] по данным о знаках первых вступлений $P$-волн, опубликованных в Бюллетене Китайской сейсмологической службы [Catalogue of earthquake..., 1980].

Реконструкция напряжений, выполненная нами [Rebetsky et al., 1997] во второй половине 90-х годов прошлого века, проведена по региону в градусном диапазоне по долготам от $50^{\circ}$ в.д. до $170^{\circ}$ в.д. и по широтам от $10^{\circ}$ ю.ш. до $70^{\circ}$ с.ш. Новая реконструкция напряжений, представляемая в настоящей работе, выполнена для меньшей территории (65-100 $45^{\circ}$ с.ш.), которая соответствует району Средней и Юго-Восточной Азии, именуемому как Высокая Азия [Burtman, 2012].

Следует также заметить, что в современном виде MКА состоит из четырех этапов, в рамках которых определяются разные компоненты напряженного состояния. Тот вариант МКА, который использовался на момент времени конца прошлого века, отвечал сегодняшнему первому этапу МКА в несколько урезанном виде. Так, на первом этапе современной версии МКА определение параметров эллипсоида напряжений и параметров эллипсоида приращений сейсмотектонических деформаций ведется совместно. В версии МКА 1997 г. этого не было.

Другой метод расчета параметров тензора напряжений для коры Китая был использован в работе Зхонгхуа Ху [Zhonghuai et al., 1992]. Теоретические его основы ближе к известному у нас в стране методу расчета квазиглавных напряжений В.Д. Парфенова [Parfenov, 1984]. В этой работе, как и почти во всех далее представленных, анализировалась ориентация главных осей рассчитываемых параметров напряженно-деформированного состояния коры и осуществлялось сопоставление с тектоническими структурами района исследований.

В работе [Trifonov et al., 2002] для коры АльпийскоГималайского коллизионного пояса были выполнены расчеты тензора приращений сейсмотектонических деформаций (СТД) по методике Ю.В. Ризниченко [Riznichenko, 1968] с применением уточнений, сделанных в работе [Kostrov, 1975]. При этом использовались каталоги механизмов очагов землетрясений с магнитудами $M_{b} \geq 5$ [Mostryukov, Petrov, 1994; Balakina et al., 1996] и ТИССС АН Таджикистана. Параметры тензора приращений СТД рассчитывались в центрах окон с размерами $1^{\circ} \times 1.25^{\circ}$ и $3^{\circ} \times 3.75^{\circ}$ с перекрытием на $1^{\circ}$ и $1.25^{\circ}$. Такой режим расчета отвечает усреднению тензора СТД соответственно около 120 и 360 км по ла- 

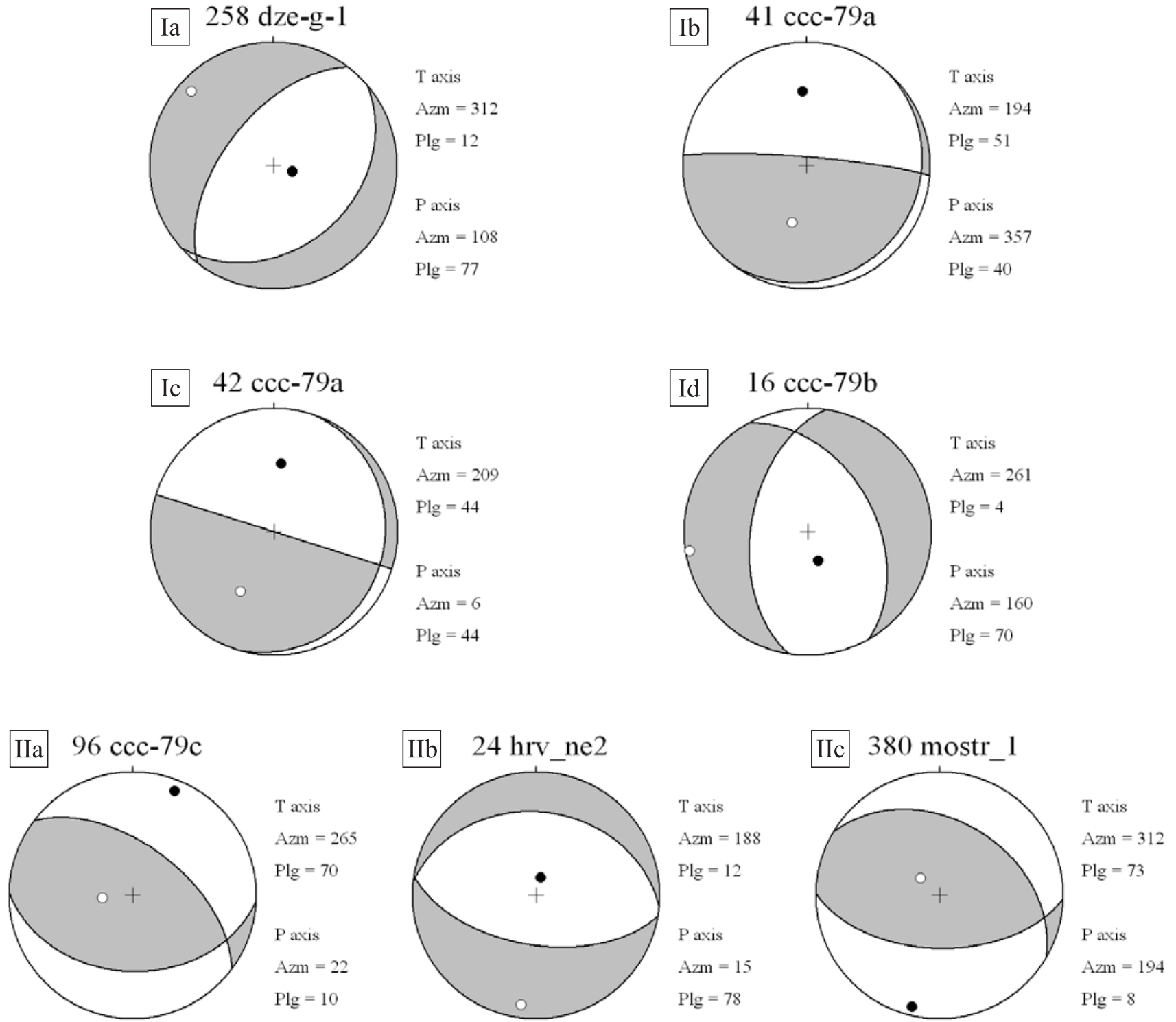

Рис. 2. Сравнение механизмов очагов, полученных разными авторами для одного и того же землетрясения (см. таблицу).

Показаны четыре варианта решения механизма очага первого землетрясения $(\mathrm{I} a-d)$ и три варианта решения механизма очага второго землетрясения (II $a-c)$.

Fig. 2. Comparison of focal mechanisms reconstructed by different researchers for the same earthquakes (see Table).

Four variants of focal mechanism solution for the first earthquake (Ia-d) and three variants of focal mechanism solution for the second earthquake (IIa-c) are shown.

терали и по всей мощности коры. В более поздней работе О.А. Кучай [Kuchai, Bushenkova, 2009] изучение напряженно-деформированного состояния коры Высокой Азии от Гималаев до Алтая и Саян также выполнялось на основе расчета тензора приращений СТД. Эти данные дополнялись анализом ориентации осей $P$ и $T$ сброшенных напряжений в очагах сильных землетрясений,

Так же широко известны результаты проекта «World stress map» [Zobak, 1992], в рамках которого в мировую карту напряжений были включены данные об ориентации осей главных снимаемых напряжений $P$ и
$T$ в очагах наиболее сильных землетрясений $\left(M_{b} \geq 7\right)$. На карту в точке, отвечающей эпицентру очага сильного землетрясения, наносились проекции осей $P$ на горизонтальную плоскость. Выполнялось разделение напряженных состояний по кинематическим типам очага землетрясения: взброс, сброс, сдвиг по простиранию. В работе [Zobak, 1992] фактически утверждалось, что оси $P$ и $T$ механизмов очагов сильных землетрясений совпадают по ориентации с осями главных тектонических напряжений.

Позднее в работе [Sherman, Lunina, 2001] карта напряжений М.Л. Зобак в областях, где в ней отсутство- 
вали данные, была дополнена информацией о напряжениях, полученных в работах других исследователей, а также на основе интерпретации серии региональных тектонических карт и Международной тектонической карты Мира [International tectonic map..., 1984]. На карте глобального напряженного состояния С.И. Шермана и О.В. Луниной не строились оси главных напряжений. Здесь разным цветом закрашены участки коры с различными типами геодинамической обстановки: горизонтального растяжения, сжатия, сдвига и т.Д.

В продолжение подхода М.Л. Зобак в работах [Coblentz, Richardson, 1995; Heidbach et al., 2007, 2008, 2010] с использованием только механизмов очагов землетрясений получены новые данные о поле глобальных напряжений. Здесь результаты проекта «World stress map» [Zobak, 1992] в части механизмов очагов были дополнены новыми сейсмологическими данными о более поздних сильных землетрясениях. С целью более плотного покрытия поверхности Земли данными о напряженном состоянии ее коры в указанных выше работах выполнялось усреднение и интерполяция ориентации проекций на горизонтальную плоскость осей $P$ на участки коры, где данных о сильных землетрясениях не было. Радиус усреднения составлял от 100 до 1000 км. Этот же способ построения карты глобальных напряжений был применен в работе [Koptev et al., 2011]. Подобный подход по усреднению механизмов в чем-то схож с методом расчета среднего механизма по С.Л. Юнге [Yunga, 1990]. Здесь данные о напряжениях получают на основе усреднения и последующей интерполяции механизмов очагов землетрясений, с главными осями которых отождествляют главные оси искомых главных напряжений.

В нашей работе будет проведено сопоставление результатов исследований современного напряженного состояния, полученного в предыдущих работах, с нашими новыми результатами реконструкции напряжений.

\section{3. МЕТОДИЧЕСКИЕ АСПЕКТЫ ПРОВЕДЕННЫХ ИССЛЕДОВАНИЙ}

В предыдущем разделе было отмечено, что ранее для коры Высокой Азии разными методами было выполнено несколько реконструкций напряженного состояния по сейсмологическим данным о механизмах очагов землетрясений. Эти результаты имеют как определенную общность, так и достаточно сильные различия. Подобная ситуация предопределяет возникновение вопроса об отношении к этим результатам. Отвечая на него, надо прежде всего оценить качество методов, используемых для реконструкции напряжений.

Начнем наш анализ с методики расчета тензора приращений СТД в том виде, как она была применена в работе [Trifonov et al., 2002]. Ее методические про- блемы и возможные ошибки расчета достаточно подробно рассмотрены в работе [Rebetsky, 2007a]. Самая главная проблема подобного подхода состоит в том, что в нем суммирование вкладов сейсмотектонических деформаций, приписываемых затем данной точке пространства, возможно даже в случае диаметрально противоположных механизмов очагов, таких как взброс и сброс с одинаковым простиранием нодальных плоскостей. В этом случае при близких магнитудах землетрясения сумма двух таких вкладов будет равна нулю. Вторая очень важная проблема в подходе, реализованном в работе [Trifonov et al., 2002], состоит в том, что наиболее сильное землетрясение, попавшее в окно расчета с магнитудой, на 0.5 превышающей остальные из этого же окна, фактически и определит параметры тензора приращений СТД. В работах С.Л. Юнги [Yunga, 1990] эта проблема была решена путем расчета тензора средних механизмов, но проблема суммирования разнотипных механизмов сохранилась и при нахождении среднего механизма.

В МКА также рассчитываются компоненты тензора приращений СТД. Однако их расчет осуществляется только для тех событий (механизмов очагов), которые прошли проверку критериями однородности [Rebetsky, 2007a]. Данные о параметрах СТД в МКА используются для получения единственного решения в виде параметров эллипсоида напряжений, для которого при рассчитанном тензоре приращений СТД достигается максимум диссипации энергии упругих деформаций.

Если говорить о кинематическом методе О.И. Гущенко [Gushchenko, 1979], используемом в работе [Petrov et al., 1994, 2008], то МКА следует рассматривать как его развитие. В МКА содержится целый ряд положений кинематического метода: однородные выборки механизмов очагов землетрясений; возможность несовпадения на плоскости разрыва касательных напряжений, действовавших до его активизации с направлением относительного смещения бортов и др. Эти положения были дополнены новыми требованиями, вытекающими из представлений современной теории пластичности: упорядоченностью приращений необратимых деформаций по отношению к главным осям напряжений; взаимосвязью искомого тензора напряжений и тензора приращений сейсмотектонических деформаций и др. Опыт сравнения результатов реконструкции напряжений в части ориентации осей главных напряжений, полученной этими двумя методами, показывает, что между ними нет серьезных различий.

Другая ситуация складывается с методом, используемым в статье [Zobak, 1992] и в работах последователей. Здесь в качестве осей главных тектонических напряжений принимаются направления осей $P$ и $T$ механизмов очагов сильных землетрясений. Это фактически означает, что предполагается совпадение плоскости разрыва в очаге с плоскостью действия максимальных касательных напряжений. Подобные представления существовали в геологии и в сейсмологии в 
$a$

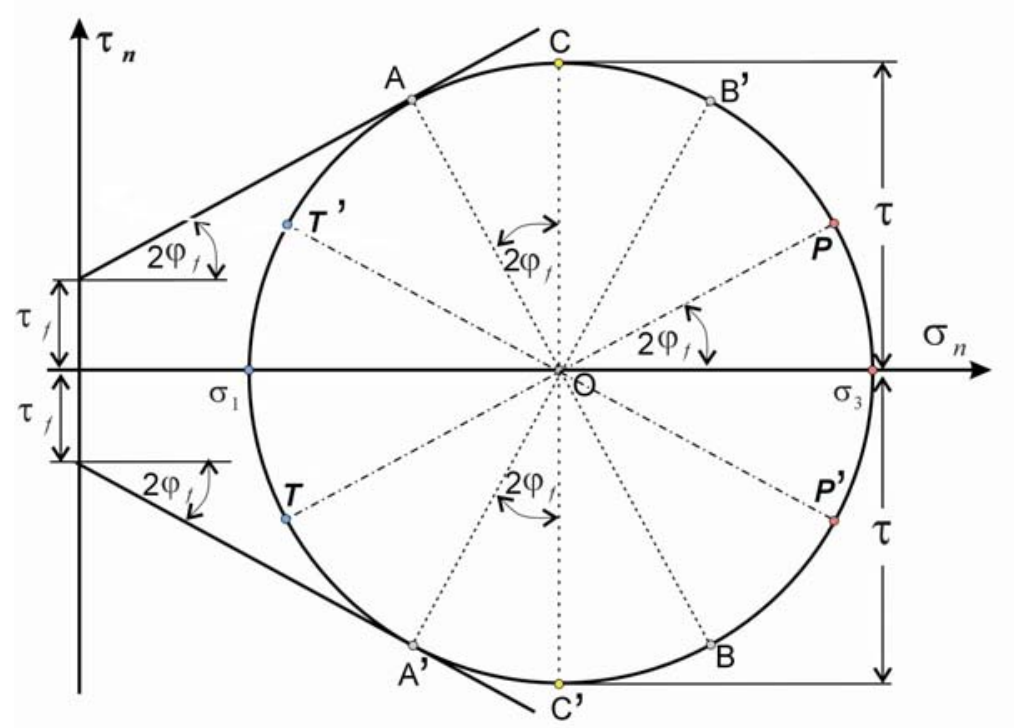

б

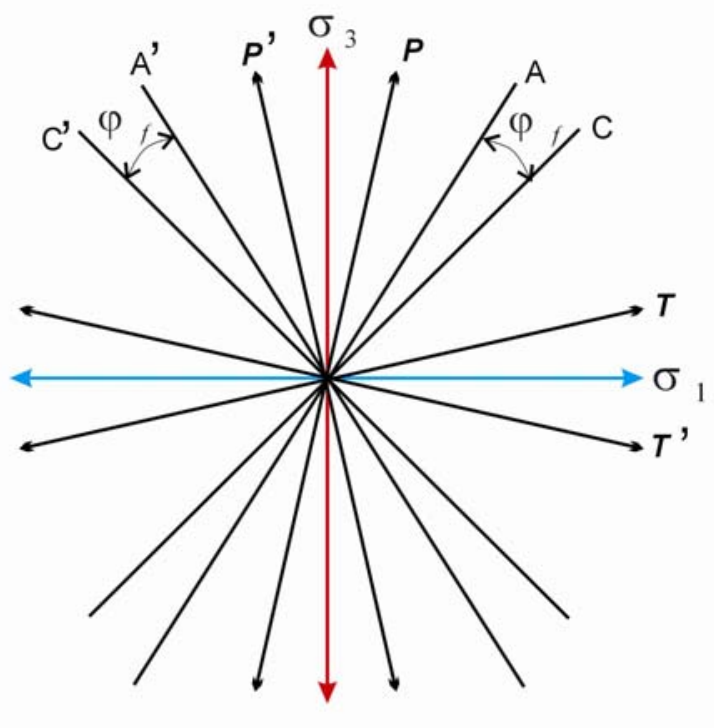

Рис. 3. Диаграмма Мора (a) и схема ориентации главных осей напряжений, плоскостей скалывания и максимальных касательных напряжений (б), определяющие взаимосвязь параметров механизма очага землетрясения и главных напряжений. $A, B, P, T$ - индексы для напряженных состояний на двух нодальных плоскостях и для нормальных напряжений вдоль главных осей сжатия и растяжения снимаемых напряжений для первого варианта очага, $A^{\prime}, B^{\prime}, P^{\prime}, T^{\prime}-$ такие же индексы для второго варианта очага.

Оба землетрясения имеют одну нодальную плоскость, совпадающую с одной из сопряженных плоскостей скалывания. Пояснение в тексте.

Fig. 3. The Mohr diagram (a) and scheme of orientations of principal stress axes, fault planes and maximum shear stresses (б) which determine correlations between parameters of earthquake focal mechanisms and the principal stresses. $A, B, P, T-$ indices for the states of stresses at the two nodal planes and for normal stresses along principal axes of compression and extension of released stresses for earthquake I; $A^{\prime}, B^{\prime}, P^{\prime}, T^{\prime}$ - similar indices for earthquake II.

Both earthquakes have one nodal plane coincident with one of the conjugated shear planes. See explanation in the text.

первой половине прошлого века, но после экспериментальных исследований [Mogi, 1964; Byerlee, 1968, 1978; Brace, 1978; Stavrogin, Protosenya, 1992] были отвергнуты. В экспериментах было показано, что трещины в изначально однородных и ненарушенных образцах горных пород развиваются вблизи положения плоскости скалывания. Для образцов, имевших предварительно подготовленные внутренние дефекты прочности, хрупкое разрушение может развиваться на плоскостях трещин, имеющих достаточно сильное отклонение от ориентации плоскости скалывания [Rebetsky, 2007b].

Таким образом, при обсуждении методических основ работы [Zobak, 1992] нам приходится вернуться на 40 лет назад к известным дискуссиям, возникшим в работах Б.В. Кострова [Kostrov, 1975] и А.В. Введенской [Vvedenskaya, 1969], о том, можно ли в качестве тектонических напряжений прямо использовать данные об ориентации снимаемых напряжений в очагах единичных сильных землетрясений. И хотя в теоретических работах Б.В. Кострова и в практических реконструкциях [Gushchenko, 1996; Rebetsky, 2007a] было показано, что этого делать нельзя, многие авторы продолжают идти этим более простым путем, который является менее достоверным по получаемым результатам.

Иллюстрация неточности в понимании взаимосвязи тензора напряжений с морфологией хрупкого разрушения, вытекающая из подхода А.В. Введенской и М.Л. Зобак, приведена на рис. 3, а. Для хрупкого разрушения однородно деформируемых образцов характерно совпадение положения плоскости трещин с плоскостью скалывания горной породы. Плоскости скалывания представляют собой сопряженную пару, каждая из которых отклоняется от плоскости действия максимальных касательных напряжений в сторону оси максимального сжатия $\left(\sigma_{3}\right)$ на угол $\varphi_{f}$ (рис. $\left.3, \sigma\right)$. На диаграмме Мора (рис. 3, $a$ ) нормальному $\sigma_{\mathrm{n}}$ и касательному $\tau_{\mathrm{n}}$ напряжениям на этих плоскостях отвечают точки $A$ и $A$ ', лежащие на большом круге Мора соответственно в верхнем и нижнем его секторах. Углу между этими плоскостями и плоскостями действия максимального касательного напряжения $\tau$ (точки $C$ и $\left.C^{\prime}\right)$ в моровой параметрической области отвечает угол 
$2 \varphi_{f}$. На моровой параметрической области все углы между нормалями $n$ к плоскостям, попадающим на большой круг Мора, увеличиваются вдвое по отношению к нашему трехмерному пространству (рис. 3, б). Считается, что для горных пород угол $\varphi_{f}$ может изменяться в диапазоне $13-18^{\circ}$.

Будем полагать, что точка $A$ определяет напряжения, действующие на плоскости очага землетрясения (первая нодальная плоскость). Т.е. плоскость очага землетрясения совпадает с плоскостью скалывания для тензора напряжений, действующего в окрестности очага. Отметим, что наши исследования [Rebetsky, 2007a] показывают, что чем выше магнитудный уровень землетрясения, тем чаще встречается ситуация, когда реализованная в очаге плоскость на диаграмме Мора близко расположена к плоскости скалывания. Это не является правилом, а лишь встречается в какихто районах более, а в каких-то менее часто.

Найдем на диаграмме Мора напряжения, отвечающие второй нодальной плоскости, сопряженной с плоскостью $A$. Этой плоскости будет отвечать точка $B$. Нормали к плоскостям для этих точек отличаются в моровом пространстве на $180^{\circ}$, что в нашем пространстве как раз и дает необходимые 90. Мы видим, что точка $B$ очень далеко отстоит от точки $A^{\prime}$, определяющей положение сопряженной плоскости скалывания. Это говорит о том, что вторая нодальная плоскость не может реализоваться в качестве разрыва в данном напряженном состоянии. Сопряженной паре нодальных плоскостей $A$ и $B$ механизма очага землетрясения будут отвечать главные снимаемые напряжения, действующие на плоскостях, отклоняющихся от плоскостей $A$ и $B$ на $45^{\circ}$ в нашем пространстве и на $90^{\circ}$ в моровом. На рис. 3, a, напряжения, действовавшие на этих плоскостях до активизации разрыва, показаны точками $P$ и T. Видно, что на этих плоскостях действовали касательные напряжения, а нормальные напряжения отличаются как по величине, так и по направлению (в нашем пространстве на угол $\varphi_{f}$ ) от главных напряжений соответственно $\sigma_{3}$ и $\sigma_{1}$.

Если теперь сопряженную плоскость скалывания A', рассматриваемого на рис. $3, a$, напряженного состояния, принять в качестве плоскости очага другого землетрясения, то ей будет отвечать сопряженная нодальная плоскость $B^{\prime}$ и снимаемые напряжения $P^{\prime}$ и $T^{\prime}$. Мы видим, что оси этих снимаемых напряжений, так же как и для первого очага землетрясения, отличаются от положения осей главных напряжений $\sigma_{3}$ и $\sigma_{1}$ на угол $\varphi_{f}$, который при этом отсчитывается в противоположном направлении.

Результаты выполненного анализа говорят о следующем: если для какого-то участка коры будут существовать два землетрясения, плоскости очага которых совпадали с сопряженными плоскостями скалывания действующего здесь напряженного состояния, то ориентации соответственно $P$ и $T$ осей этих землетрясений будут отличаться на угол $2 \varphi_{f}$. При этом оси $P$ и $T$ каждого из землетрясений будут отличаться от ориентации главных напряжений на угол $\varphi_{f}$ (рис. 3, б).

Таким образом, применение подхода А.В. Введенской и М.Л. Зобак помимо высокой неустойчивости ориентации главных осей напряжений, определяемых по положению осей $P$ и $T$ механизмов очагов сильных землетрясений, имеют систематическую ошибку 13-18 . Это положение может подправить методика В.Д. Парфенова по определению в качестве квазиглавных напряжений центра облака выходов на единичную полусферу соответственно осей $P$ и $T$ отдельных механизмов. Однако здесь более важно само непонимание авторов, применяющих эти подходы, закономерности взаимосвязи морфологии хрупкого разрушения и параметров тензора напряжений, которое затем проявляется и в интерпретации получаемых данных о напряженном состоянии.

\section{4. РЕЗУЛЬТАТЫ РЕКОНСТРУКЦИИ НАПРЯЖЕНИЙ ДЛЯ КОРЫ ВЫСОКОЙ АЗИИ ЗА ПЕРИОД 1904-1992 ГГ.}

В рамках настоящей статьи по результатам расчетов 1996-1997 гг. [Rebetsky et al., 1997] были вновь построены карты некоторых параметров напряженного состояния для коры в пределах района Высокой Азии (60-100 в.д. и 20-55 с.ш.), включающих районы горных областей Памира, Афганского поднятия, Гиндукуша, Тянь-Шаня, Гималаев, Куньлунь и Тибета (см. рис. 1). Территория этих горных поднятий к северу сопрягается с крупнейшей в Азии впадиной Таримской плиты, Предтяньшаньской и Ал Шань впадинами, а также с пустыней Гоби. С востока рассматриваемая область ограничивается зоной сдвигов Красной реки, Сычуанской котловиной и Китайским лессовым плато. С запада ограничениями являются впадина Гильменд и Афганская депрессия.

Расчеты напряжений производились на нерегулярной сетке, отвечающей латеральным координатам эпицентров очагов относительно сильных землетрясений, и глубине 20 км. Расчет напряжений, приведенный в работе [Rebetsky et al., 1997], выполнялся для большей территории (Юго-Восточная Азия и Океания), чем в настоящей работе. В нем были получены данные о параметрах тензора напряжений для 5883 доменов коры. Из этого объема исходных данных были выбраны 1286 доменов, попадающих в исследуемый нами район Высокой Азии. Поскольку эпицентры землетрясения часто формировали кластеры, то при построении некоторых параметров тензора напряжений (ориентации главных осей и направления поддвиговых касательных напряжений на горизонтальных площадках) для улучшения изображения выполнялось прореживание результатов расчетов (убирались одинаковые и рядом расположенные ориентации соответствующих векторов). После прореживания для оставшихся 385 доме- 
нов коры были показаны соответствующие параметры тензора напряжений.

На рис. 4 представлены данные об ориентации осей главных напряжений $\sigma_{1}$ и $\sigma_{3}$. Здесь построены проекции погружения осей этих напряжений на сферическую поверхность Земли. Из результатов реконструкции видно, что для исследуемой части коры Высокой Азии оси $\sigma_{1}$ и $\sigma_{3}$ образуют радиально-концентрическую систему линий.

Большинство осей $\sigma_{1}$ субпараллельны границе столкновения Индийской и Евразийской плит и создают систему обтекания в пределах восточного угла Индийской плиты и сложного сопряжения для коры Памира. Оси напряжений максимального сжатия на большой территории субгоризонтальны, имеют северо-восточную ориентацию и практически субортогональны северной границе Индийской плиты. Они сохраняют такую свою ориентацию на больших расстояниях, несколько разворачиваясь на восток вблизи югозападных границ Байкальской рифтовой системы.

Существенный разворот анализируемых осей главных напряжений наблюдается в юго-восточном секторе исследуемого региона в пределах синтаксиса Намче Барва и зоны сдвигов Красной реки. Здесь оси $\sigma_{3}$ испытывают разворот на $180^{\circ}$, сменяя направление погружения с северо-восточного на юго-западное. Также на $180^{\circ}$ меняют свое погружение и оси $\sigma_{1}$.

Подобная ориентация осей главных напряжений хорошо соответствует идеям об индентерном влиянии Индийской плиты на напряженное состояние коры Высокой Азии, рассматривавшимся в известной работе [Molnar, Tapponnier, 1975].

Наибольшие отклонения от субгоризонтального положения осей максимального сжатия наблюдаются в коре Северо-Кызылкумской впадины (рис. 4, б). Здесь оси этого напряжения субвертикальны. Также наблюдаются достаточно крутые погружения осей $\sigma_{3}$ для участков коры Центрального Памира и Восточного Тибета.

В коре Гималаев, Западного Памира, Гиндукуша, а также Западного и Центрального Тянь-Шаня оси алгебраически наибольшего из главных напряжений $\sigma_{1}$ субвертикальны (рис. 4, a). Оси промежуточного главного напряжения $\sigma_{2}$ субвертикальны для большинства областей Тибета и в коре зоны сдвигов Красной реки.

Далее на рис. 5 представлены параметры, характеризующие геодинамический тип напряженного состояния и тип тензора напряжений. При геодинамическом районировании коры использовалось деление напряженных состояний на шесть типов, отвечающих различным углам оси на зенит в октанте, построенном на трех главных осях напряжений (врезка рис. 5, a) [Gushchenko, 1996; Gushchenko et al., 1990; Sherman, Dneprovsky, 1989; Rebetsky, 2007a]. Как видно из рис. 5, $a$, большая часть коры Высокой Азии отвечает режиму горизонтального сдвига с субвертикальной ориентацией промежуточной оси главного напряжения
(Тибет, Центральный Тянь-Шань, Афганское поднятие, зона сдвигов Красной реки). Так же широко представлен режим горизонтального сжатия с субвертикальной ориентацией оси алгебраически максимального напряжения (горные области Центральных Гималаев, Северный Памир и Гиндукуш, Западный и Восточный Тянь-Шань, северный борт Таримской плиты). В коре центральной части Памира и Северо-Кызылкумской впадины наблюдается режим горизонтального растяжения с субвертикальной осью максимального сжатия.

Еще одна характеристика напряжений - коэффициент Лоде - Надаи $\left(\mu_{\sigma}\right)$, определяющий тип эллипсоида (тензора) напряжений, - в пределах исследуемого региона также испытывает максимально возможные изменения (рис. 5, б). Для коры Афганского поднятия, Восточного Тянь-Шаня и Монгольского Алтая к западу от зоны сдвигов Красной реки наблюдается тип тензора, близкий к одноосному сжатию. Тензор, близкий к одноосному растяжению, характерен для коры синтаксиса Намче Барвы, западной части Таримской плиты и Западного Памира. Области коры с тензором одноосного растяжения и одноосного сжатия разделяются зонами коры с тензором, близким к чистому сдвигу. Коре центральной части Тибета также отвечает тензор, близкий к чистому сдвигу.

Из результатов геомеханического теоретического анализа известно, что тип напряженного состояния играет большую роль в разрушении геоматериалов [Makarov, 2010]. Повреждения в виде хрупких трещин и разрывов в областях одноосного растяжения - чистого сдвига $\left(\mu_{\sigma}<0\right)$ начинают копиться при существенно меньших напряжениях, чем при $\mu_{\sigma}>0$ в областях одноосного сжатия - чистого сдвига. Скорости накопления повреждений для локальных областей, где $\mu_{\sigma}<0$, также существенно выше, чем в областях, где $\mu_{\sigma}>0$. Эти положения геомеханики следует использовать при интерпретации результатов реконструкции природных напряжений, при прогнозе сейсмического режима территорий, при сейсмическом районировании.

Конечным итогом реконструкции первого этапа MKA являются данные об эллипсоиде напряжений, которые определяют средние для коры компоненты девиатора напряжений, нормированного на значение максимальных касательных напряжений. Имея данные о значениях редуцированного девиатора напряжений, мы знаем, в каком направлении действуют касательные напряжения на любой площадке в земной коре и как это касательное напряжение соотносится с максимальным касательным напряжением.

Данные о девиаторе напряжений позволяют увидеть взаимосвязь деформаций коры с мантией. Для этого необходимо построить направления касательных напряжений, действующих на горизонтальных площадках. Если изобразить эти направления для площадок, нормали которых смотрят к центру Земли (ось Z), 

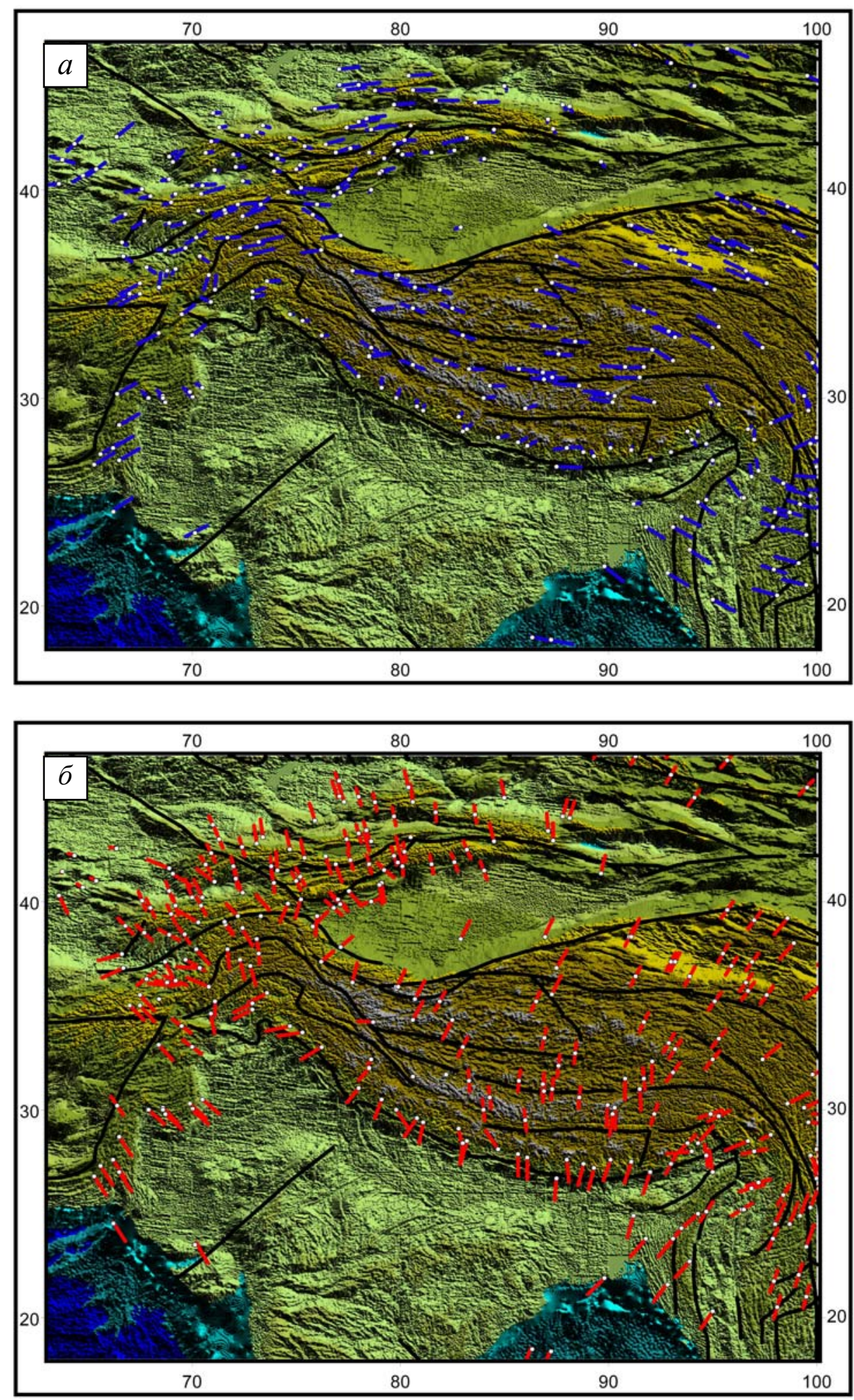

Рис. 4. Проекции на горизонтальную плоскость осей главных напряжений: $a-\sigma_{1} ; \sigma-\sigma_{3}$ по результатам реконструкции [Rebetsky et al., 1997].

Вектор из точки, отвечающей эпицентру землетрясения, направлен в сторону погружения оси главного напряжения. Точка в середине вектора означает субгоризонтальное положение оси $\left( \pm 15^{\circ}\right)$. Длина проекции характеризует крутизну погружения вектора. Построение проекций выполнялось на прореженной нерегулярной сетке результатов расчетов.

Fig. 4. Projections of principal stress axes to the horizontal plane: $a-\sigma_{1} ; \sigma-\sigma_{3}$ as reconstructed in [Rebetsky et al., 1997].

Vectors from points corresponding to earthquake epicenters are directed towards dips of principal stresses. Points at the middle of vectors show subhorizontal positions of axes $\left( \pm 15^{\circ}\right)$. Projection lengths characterize the steepness of vector plunge. Projections are done at the subsampled grid of calculation results. 

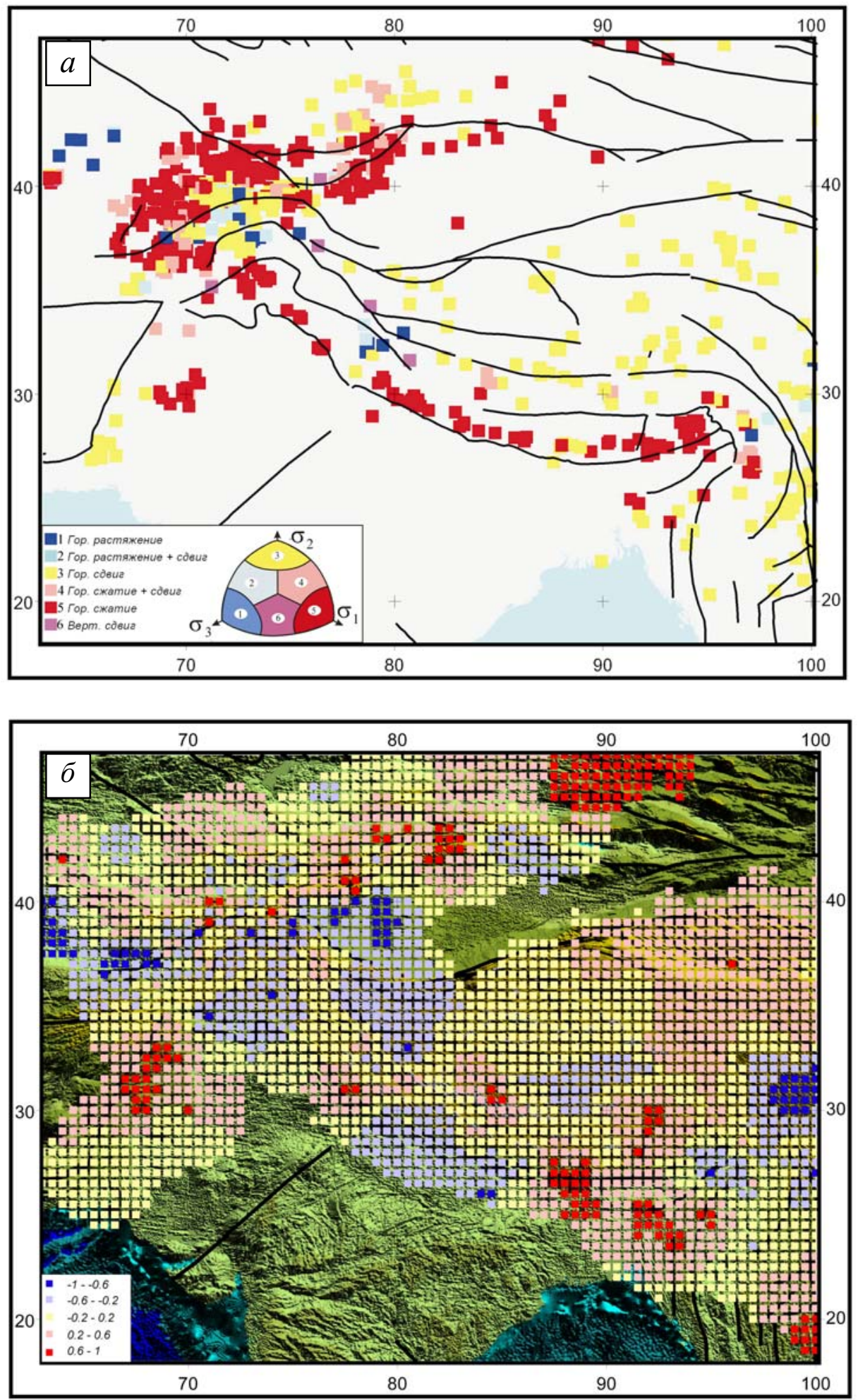

Рис. 5. Геодинамический тип напряженного состояния и вид тензора напряжений (коэффициент Лоде - Надаи) в коре Высокой Азии по результатам реконструкции [Rebetsky et al., 1997].

Построение выполнялось на полной нерегулярной сетке результатов расчетов. В нижней части рисунка приведено расположение выделяемых геодинамических типов в октанте, построенном на осях главных напряжений. Попадание оси на зенит в соответствующий сектор этого октанта определяет один из шести типов напряженного состояния, принятых в геодинамике.

Fig. 5. The geodynamic type of the state of stresses and the stress tensor (the Lode - Nadai coefficient) of the crust in High Asia as reconstructed in [Rebetsky et al., 1997].

The full subsampled grid of calculation results is used. Locations of identified geodynamic types in the octant constructed at the axes of principal stresses are shown at the bottom of the figure. One of the six types of the state of stresses accepted in geodynamics is determined by positioning of the axis at the zenith of the corresponding sector of the octant. 


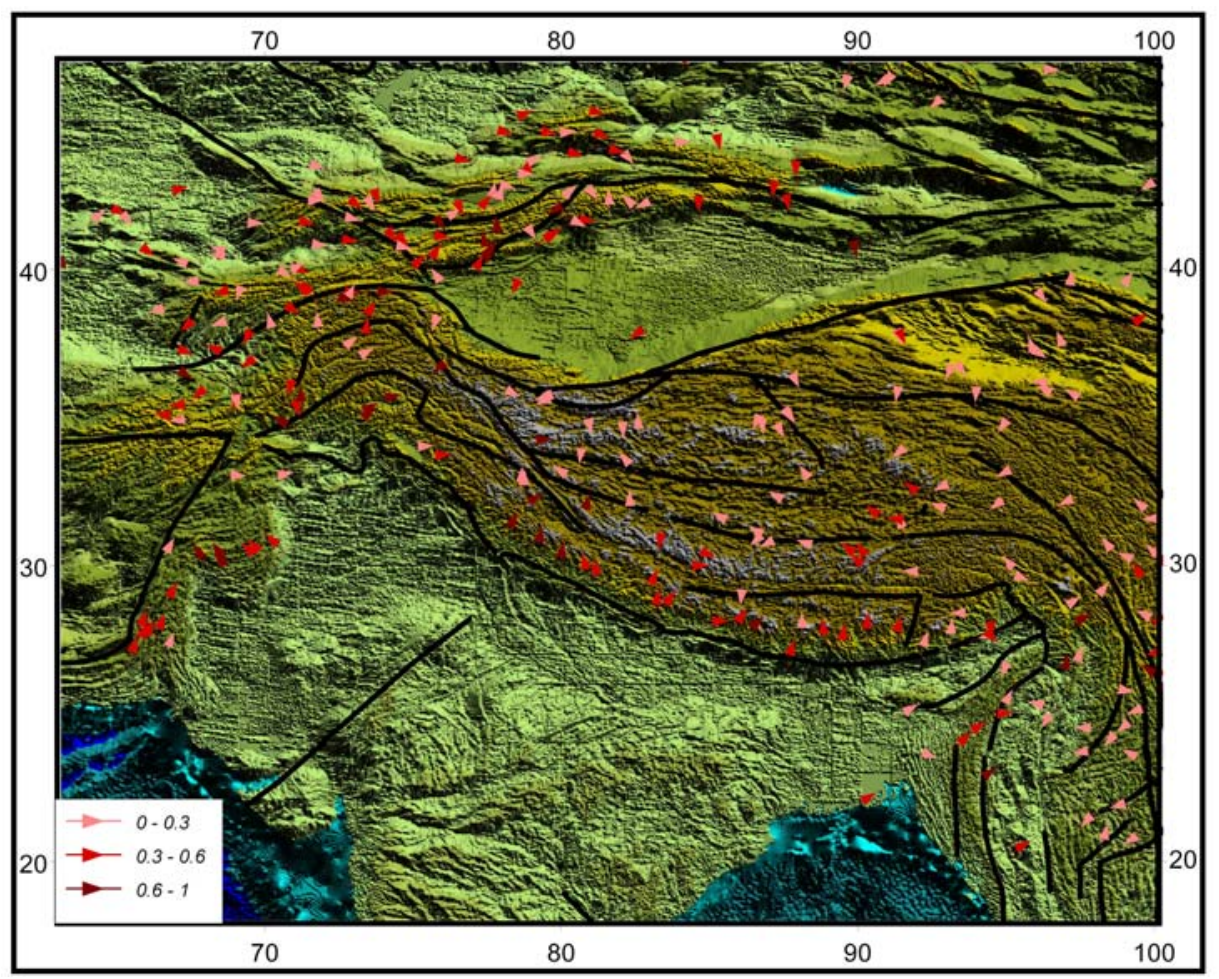

Рис. 6. Ориентации поддвиговых касательных напряжений, действующие на горизонтальных площадках с нормалями к центру Земли по результатам реконструкции [Rebetsky et al., 1997].

Построение выполнялось на прореженной нерегулярной сетке результатов расчетов.

Fig. 6. Orientations of underthrusting shear stresses acting at the horizontal planes and normals to the center of the Earth as reconstructed in [Rebetsky et al., 1997].

The full subsampled grid of calculation results is used.

то они будут указывать направления относительного смещения вещества коры и мантии. Данные касательные напряжения $\tau_{\mathrm{z}}$ можно именовать поддвиговыми, так как они характеризуют вертикальную неоднородность кинематики коры.

На рис. 6 показаны направления таких касательных напряжений в коре исследуемого региона. Видно, что для Гималаев они везде ориентированы в северо-восточном направлении, что говорит о большей скорости смещений мантии относительно коры в этом направлении. Здесь эти горизонтальные площадки также достаточно близки к площадкам действия максимальных касательных напряжений. Подобное распределение этих осей может иметь двойную интерпретацию. Первая говорит о том, что подошва коры Гималаев испытывает интенсивное воздействие со стороны мантии в направлении на северо-восток. Результатом такого воздействия должно быть смещение коры также на северо-восток.

Другой вариант интерпретации говорит о смещении на юго-запад коры Тибета относительно мантии и ее надвигании на Индийскую плиту. Оба варианта интерпретации имеют право на существование, и оба этих варианта не противоречат известным данным GPS- геодезии.

Уже в пределах коры южной части Тибета эта стабильная ориентация осей $\tau_{\mathrm{z}}$ пропадает, и здесь можно увидеть совершенно разные ориентации касательных напряжений на горизонтальных площадках, включая противоположные - юго-западные. При этом в коре всего Тибета уровень касательных напряжений $\tau_{z}$ очень низкий. Устойчивые определения ориентации поддвиговых напряжений и высокий их уровень в коре Тибета наблюдаются пятнами. Так, в северной части коры существует область с устойчивой ориентацией поддвиговых касательных напряжений на юг, а в северо-восточном сегменте - на восток - северо-восток. Немного восточнее это направление сменяется субмеридиональным направлением на юг. Во всех остальных доменах с данными о напряжениях $\tau_{\mathrm{z}}$ горизонтальные площадки достаточно сильно отклонены от плоскостей действия максимальных касательных напряжений, что определяет низкий уровень этих напряжений и достаточно сильный разброс в их ориентации.

Полученные данные о направлениях поддвиговых касательных напряжений в коре Тибета (отсутствие одного направления) отражают относительно стабильное сосуществование коры и мантии, т.е. здесь на по- 
$a$

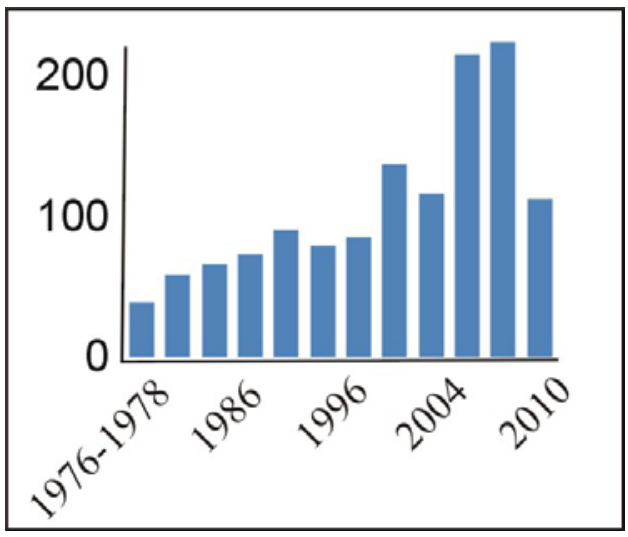

$\sigma$

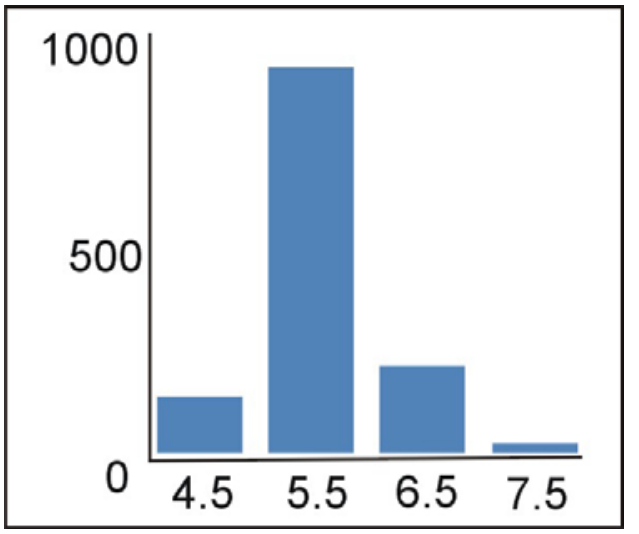

8

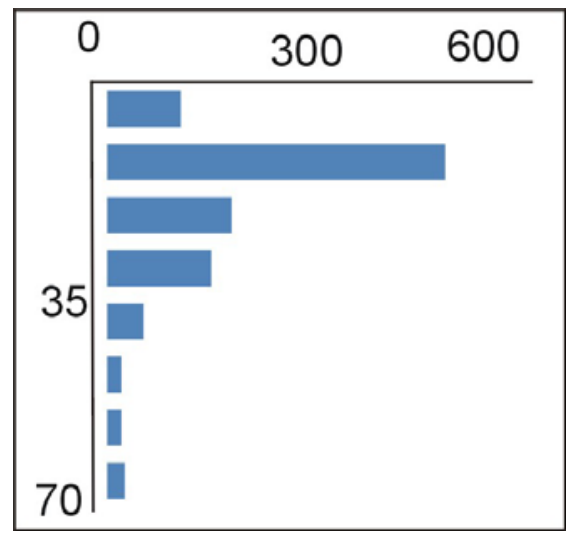

Рис. 7. Диаграммы распределения числа событий из каталога в период 1978-2010 гг. по годам (a), по магнитудам (б) и глубинам (в).

Fig. 7. Diagrams showing distribution of numbers of events from the catalog for the period from 1978 to 2010 years by years (a), magnitudes (6) and depths ( 8 ).

дошве коры не наблюдается значимых сил, которые должны были бы возникать при индентерном воздействии Индийской плиты на Тибет. Это говорит либо о том, что такого воздействия здесь нет, либо о том, что горизонтальному сжатию подвержена не только кора, но и вся литосфера, и здесь нет проскальзывания на север утолщенной коры Тибета (около 70 км) относительно мантии.

В коре Памира поддвиговые касательные напряжения ориентированы достаточно хаотично, а в коре Тянь-Шаня в целом дают восточно - юго-восточное направление. Так же слабо выражены единые ориентации этих напряжений в коре синтаксиса Намче Барва.

Анализ полученных результатов показал, что главные особенности реконструированного поля современных тектонических напряжений Юго-Восточной Азии состоят в том, что изменение ориентаций осей главных напряжений носит закономерный характер с высоким уровнем равномерности. В зоне сочленения Индийской и Евразийской плит оси главных сжимающих напряжений также направлены по нормали к простиранию Памиро-Гималайской сейсмоактивной области с направлением падения под Индийскую плиту. Отметим характерное радиальное субгоризонтальное распределение направлений осей этого напряжения для обширных областей Средней Азии и Китая. Направления осей двух других главных напряжений образуют здесь радиально-концентрическое поле траекторий главных напряжений. На основании описанной выше возможности кинематической интерпретации траекторий главных нормальных напряжений можно сделать заключение, что Индийская плита надвигается на Евразийскую плиту в северо-восточном направлении (отклонение от направления на север в пределах $\left.30-40^{\circ}\right)$, не испытывая при этом поворота.

\section{5. НОВЫЕ РЕЗУЛЬТАТЫ РЕКОНСТРУКЦИИ НАПРЯЖЕНИЙ ДЛЯ КОРЫ ВЫСОКОЙ АЗИИ ЗА ПЕРИОД 1978-2010 ГГ.}

C момента нашего предыдущего расчета параметров напряженного состояния для коры Средней и ЮгоВосточной Азии прошло более 15 лет. За этот период времени каталог Global CMT (http://earthquake.usgs.gov /eqarchives/sopor) расширился данными о механизмах очагов землетрясений по исследуемому региону в несколько раз. На момент расчета напряжений 1996 г. СМТ каталог имел данные только за 15 лет наблюдений, а сейчас период наблюдений составляет уже более 30 лет (данные о механизмах очагов помещаются в каталог с задержкой в два года). Кроме того, за прошедшее время серьезное развитие получил и МКА. В нем появились этапы расчета, позволяющие определить не только ориентацию главных осей напряжений, но и величины напряжений [Rebetsky, 2007a]. Все это подтолкнуло нас возвратиться в данный регион и выполнить повторную реконструкцию напряженного состояния.

Сформированный из каталога Global CMT региональный каталог механизмов насчитывал 1294 события с диапазоном магнитуд $4.5 \leq \mathrm{M}_{\mathrm{b}} \leq 8$ за период времени с 1976 г. по 2010 г. Для сопоставления отметим, что для этой же территории в каталоге механизмов очагов предыдущего расчета [Rebetsky et al., 1997] насчитывалось около 4500 событий.

Как следует из данных рис. 7, основной глубинный диапазон каталога механизмов очагов землетрясений лежит в интервале от 10 до 35 км. Наиболее представительным является диапазон магнитуд от 5.0 до 6.0, что связано с достаточно большими расстояниями между сейсмическим станциями IRIS. Наблюдается увеличение во времени числа событий, для которых оп- 


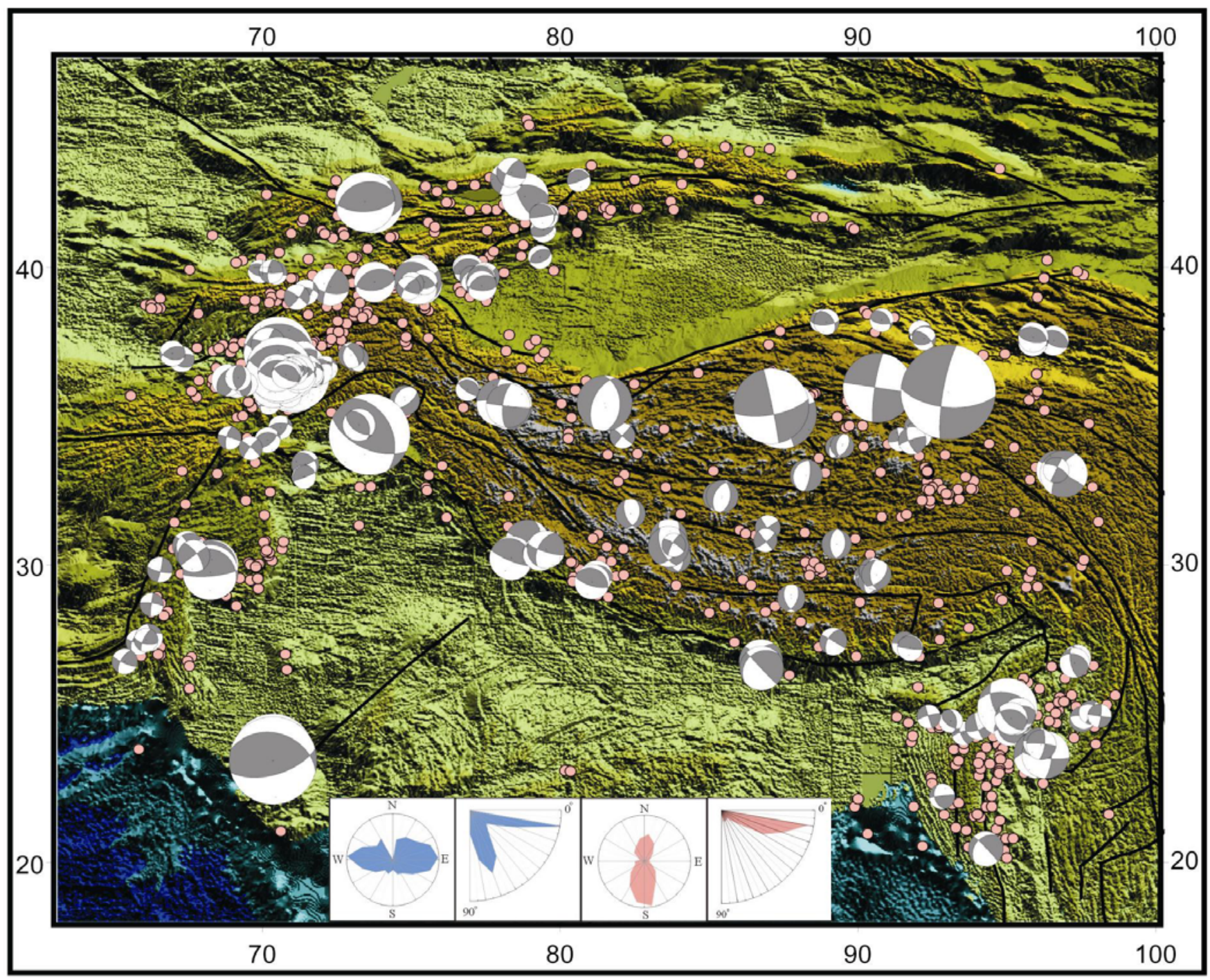

Рис. 8. Карта распределения для коры Высокой Азии эпицентров землетрясений из каталога механизмов очагов землетрясений (кружочки розового цвета) и механизмы очагов для магнитуд $\mathrm{M}_{\mathrm{b}}>6.0$, топография и основные разрывы.

На круговых роза-диаграммах в нижней части рисунка красной и синей заливкой показана представительность механизмов очагов с разной азимутальной ориентировкой и углами погружения соответственно осей $T$ (синий) и $P$ (красный).

Fig. 8. The map of the crust of High Asia showing distribution of earthquake epicenters from the catalog of earthquake focal mechanisms (pink circles), focal mechanisms of events with $\mathrm{M}_{\mathrm{b}}>6.0$, topography and main faults.

In the rose diagrams at the bottom of the figure, red and blue shading shows the representativeness of focal mechanisms with different azimuthal orientations and plunge angles of $T$ (blue) and $P$ (red) axes, respectively.

ределяются механизмы очагов землетрясений (пик приходится на 2006-2008 гг.). В следующие годы уровень сейсмичности в данном диапазоне магнитуд вернулся к значениям начала двухтысячных годов. Вероятно, данное увеличение числа сейсмических событий можно связывать с возросшей активностью региона после произошедшего 26.12.2004 г. катастрофического Суматро-Андаманского землетрясения.

На рис. 8 показано распределение эпицентров из этого каталога и механизмы очагов наиболее сильных землетрясений $\left(\mathrm{M}_{\mathrm{b}}>6\right)$. Данные каталога механизмов очагов достаточно хорошо покрывают Памир, Гинду- куш и Куньлунь. Пятнами наблюдается покрытие районов Тибета и Гималаев. В соответствии с этим распределением эпицентров событий можно ожидать и получение сведений о напряженном состоянии коры исследуемой территории.

Предварительный анализ каталога (см. диаграмму рис. 8) показал, что в нем содержится 39 \% механизмов очагов, отвечающих взбросам, $24 \%$ - сдвигам и 12 \% - сбросам. Остальные события относятся к промежуточным кинематическим типам разрывообразования, сочетающим эти основные типы. На рис. 8 на круговых диаграммах показана представительность 
азимутальных простираний и погружений осей $P$ и $T$ их механизмов. Как видно, ориентация этих осей имеет достаточный разброс в определении азимутов. Оси $P$ имеют преимущественное простирание на север и на юг при среднестатистическом пологом погружении. На диаграмме погружения этой оси проглядывается небольшой пик значений, отвечающий крутому погружению.

Оси $T$ имеют в основном субширотное простирание, но также достаточно много определений с другими ориентациями. На диаграмме погружения осей $T$ имеется два ярко выраженных пика значений. Один из них отвечает пологому положению осей, а другой субвертикальному.

Реконструкция напряжений осуществлялась для масштаба осреднения, отвечающего коре в целом (5070 км). Шаг сетки составлял $0.25^{\circ}$. При реконструкции использовались механизмы землетрясения с магнитудой от 4.5 до 6.5 (исключено 50 событий с $\mathrm{M}_{\mathrm{b}}>6.5$ ). Опыт работы алгоритма МКА показывает, что использование диапазона магнитуд, большего, чем 2.5-3.0 единицы, приводит к завышению роли сильных землетрясений за счет того, что размер их области упругой разгрузки начинает доминировать над землетрясениями меньших магнитуд. Механизмы этих сильных событий начинают участвовать в определениях напряжений большинства доменов, существенно усредняя результаты расчетов.

Расчеты выполнены для 576 квазиоднородных доменов при минимальном числе землетрясений в однородной выборке 6. Напомним, что, в отличие от этой реконструкции, в результатах, представленных на рис. 4, расчет выполнялся не по равномерной сетке, а в эпицентрах очагов землетрясений каталога механизмов.

Вполне естественно, что в результатах нового расчета ориентации осей главных напряжений (рис. 9) во многом похожи на ориентацию этих же осей для предыдущей реконструкции напряженного состояния (см. рис. 4). Так, в частности, похожа ориентация осей максимального сжатия $\sigma_{3}$ в коре западного сегмента исследуемой области, относящейся к горным поднятиям Тянь-Шаня, Памира, Куньлуня, Гиндукуша и синтаксиса Намче Барва. Здесь оси максимального сжатия закономерно сменяют свою ориентацию, оставаясь практически везде субгоризонтальными. Исключение такого субгоризонтального положения этих осей составляет кора Памира, для которой в обоих результатах реконструкции существуют домены с субвертикальной ориентацией осей максимального сжатия.

Для коры Высокой Азии наиболее обширные участки с субвертикальной ориентацией осей алгебраически максимального главного напряжения $\sigma_{1}$ наблюдаются для Гиндукуша, Афганского поднятия и ТяньШаня, что определяет наличие здесь геодинамического режима горизонтального сжатия (рис. $5, a, 10, a$ ). Для коры южной части Памира оси $\sigma_{1}$ субгоризонталь- ны, что вместе с субвертикальной ориентацией осей $\sigma_{3}$ определяет геодинамический тип напряженного состояния коры как горизонтальное растяжение. В коре северной части Памира ось максимального сжатия становится субгоризонтальной, что приводит к формированию здесь режима горизонтального сдвига.

Существенные различия в ориентации осей главных напряжений наблюдаются в коре центральной части Тибета и восточного сегмента Гималаев. Здесь оси максимального сжатия в результатах новой реконструкции имеют субвертикальную ориентацию, в то время как в расчетах, представленных на рис. 4, $a$, они субгоризонтальны (есть только несколько определений с субвертикальной ориентацией оси $\sigma_{3}$ для небольшого юго-восточного участка Тибета). Поскольку ориентация осей максимальных алгебраических напряжений $\sigma_{1}$ для обеих реконструкций похожа, это приводит к отличиям в геодинамических режимах. По результатам предыдущих расчетов (рис. $5, a$ ), здесь фиксируется режим горизонтального сдвига, а по результатам новых расчетов - горизонтальное растяжение (рис. 10, a).

В результатах нового расчета кора Южного и Восточного Тибета отличается по ориентации главных осей на зенит и, следовательно, отличается по геодинамической обстановке. Здесь (рис. 10, a) существуют большие участки коры с режимом горизонтального растяжения. В расчетах 1997 г. здесь везде режим горизонтального сдвига. Для коры Гималаев, Гиндукуша, Памира и Тянь-Шаня обе реконструкции дают близкие результаты. Также близкие результаты получены и для коры юго-восточного сектора реконструкции напряжений (кора синтаксиса Намче Барва). Диаграмма распределения числа доменов с разными типами геодинамических обстановок (в нижней части рис. $10, a)$ показывает существенное преимущество режима горизонтального сжатия.

Большие площади коры Тибета, находящиеся в режиме горизонтального растяжения (ось напряжений максимального сжатия субвертикальна), сложно интерпретировать в контексте превалирующего на сегодняшний день взгляда на геодинамику исследуемого региона. С позиции тектоники плит здесь должно наблюдаться наибольшее горизонтальное сжатие, которое передается на тысячи километров вплоть до Байкала [Molnar, Tapponnier, 1975; Seminskii, 2008]. Именно этим горизонтальным сжатием в настоящее время объясняется пятикилометровое поднятие Тибета.

Результаты новой реконструкции в расчетах коэффициента Лоде-Надаи $\mu_{\sigma}$ также имеют существенные различия с данными 1997 г. Как видно из рис. 10, б, в новых результатах для Гималаев и Тибета больше представлены домены с отрицательными значениями $\mu_{\sigma}$, т.е. здесь тензор напряжений имеет вид, промежуточный между чистым сдвигом и одноосным растяжением. В результатах за 1997 г. для этих участков коры больше доменов с положительными значениями $\mu_{\sigma}$, 

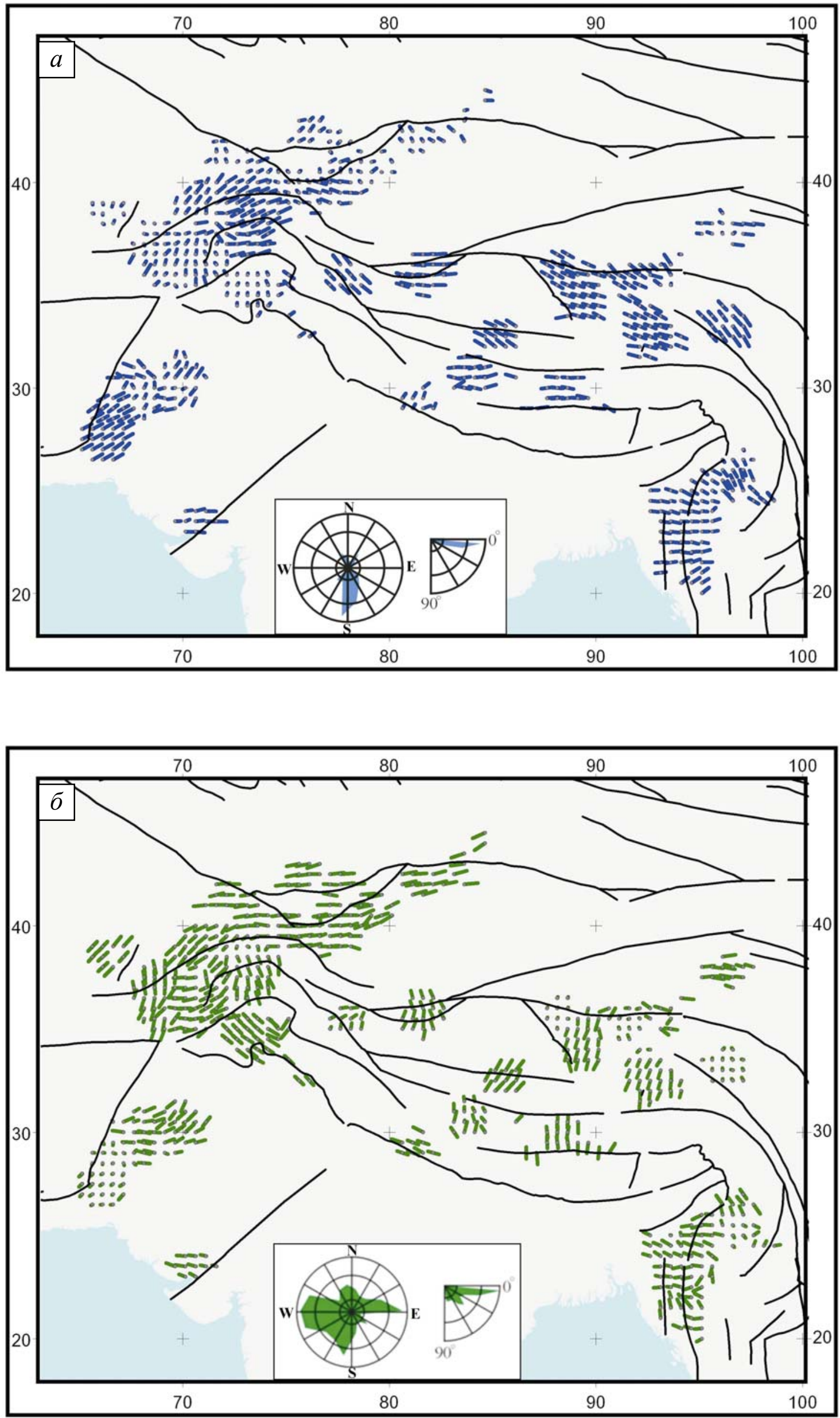


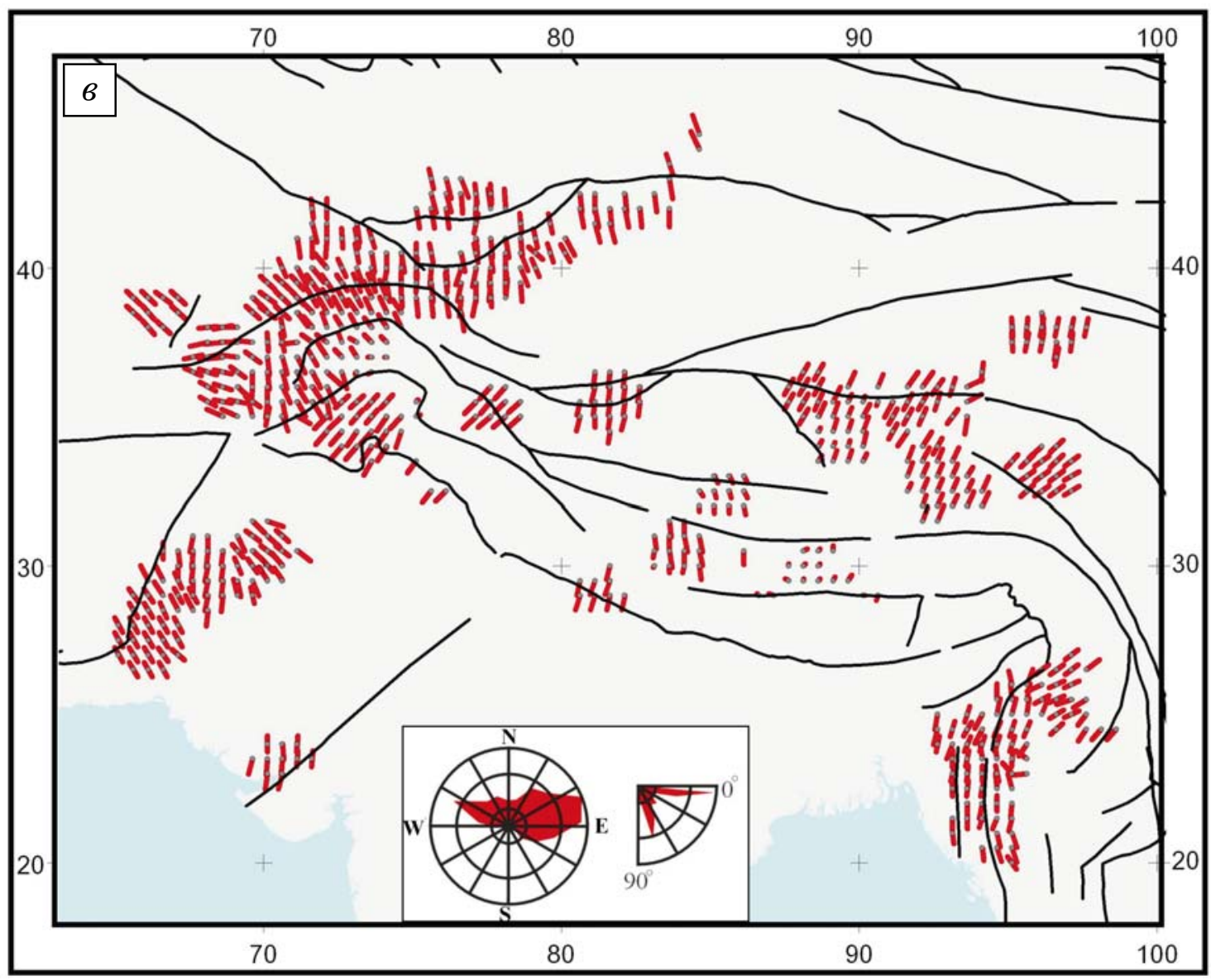

Рис. 9. Погружение осей главных напряжений, полученных по результатам новой реконструкции: $a$ - алгебраически максимального (максимального девиаторного растяжения); б - промежуточного; в - алгебраически минимального (максимального сжатия).

На круговых роза-диаграммах в нижней части рисунка для каждой из осей главных напряжений показана представительность ее азимутальной ориентировки и углов погружения. Точка - центр квазиоднородного домена, для которого выполнена реконструкции напряжений. Вектор из точки, отвечающий эпицентру землетрясения, направлен в сторону погружения оси главного напряжения. Точка в середине вектора означает субгоризонтальное положение оси $\left( \pm 15^{\circ}\right)$. Изображаемая на рисунке длина проекции характеризует крутизну погружения вектора.

Fig. 9. Plunge of principal stress axes according to the new reconstructions: $a$ - algebraically maximum (maximum deviatoric extension); $\sigma$ - intermediate; $в$ - algebraically minimum (maximum compression).

In the rose diagrams at the bottom of the figure, representativeness of azimuthal orientations and dip angles is shown for each principal stresses axis. Points show centers of quasi-uniform domains for which the stresses are reconstructed. Vectors from points corresponding to earthquake epicentres are directed towards dips of the principal stress axes. Points at the middle of the vectors show subhorizontal positions of the axes $\left( \pm 15^{\circ}\right)$. Projection lengths characterize the steepness of the vector plunges.

отвечающими тензору, промежуточному между чистым сдвигом и одноосным сжатием. Существенные различия в результатах для $\mu_{\sigma}$ наблюдаются также для юго-восточного сектора реконструкции (кора синтаксиса Намче Барва). Для коры Памира, Гиндукуша и Тянь-Шаня, наоборот, наблюдается схожесть результатов обеих реконструкций.

Сравним теперь ориентацию поддвиговых касательных напряжений, действующих на горизонтальных площадках, полученную в новых расчетах (рис. 11) и по предыдущему расчету (см. рис. 6). Видно, что для коры Гималаев ориентация $\tau_{\mathrm{z}}$ в обоих рас- четах дает северо-восточное направление при высоком уровне этих напряжений (отметим, что в новых расчетах для этого участка имеется мало данных). Такое же направление этих напряжений наблюдается в коре Куньлунь. Важным отличием новых расчетов является северо-восточная область Тибета, где поддвиговые касательные напряжения имеют прямо противоположную ориентацию - юго-восточную при среднем уровне напряжений. Для коры южной части Тибета в обеих реконструкциях наблюдается разворот осей $\tau_{\mathrm{z}}$ на $90^{\circ}$. Здесь они имеют северо-западную ориентацию. Ориентация $\tau_{\mathrm{z}}$ для «угловых» секторов» Индийской плиты 

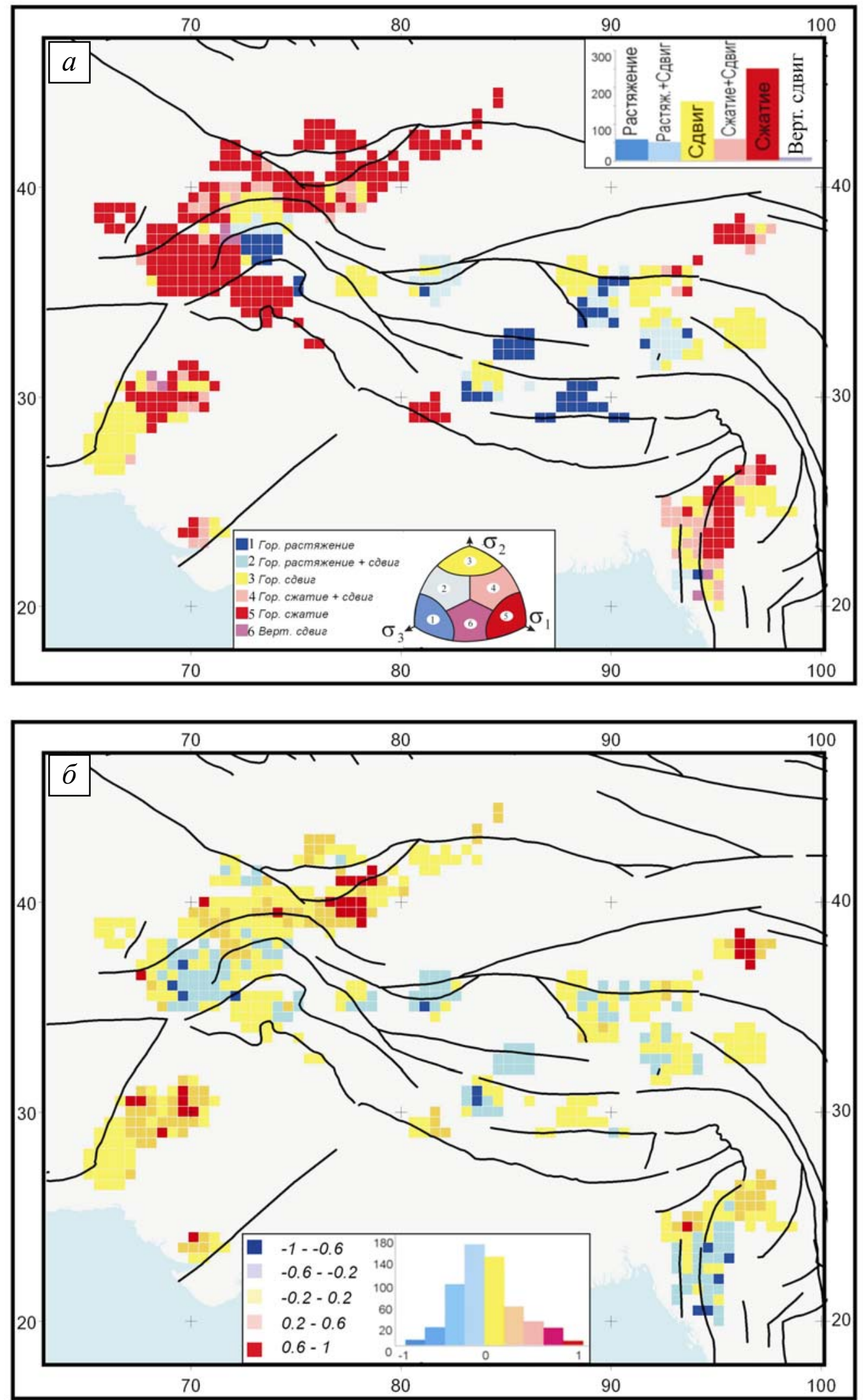

Рис. 10. Геодинамический тип напряженного состояния (a) и вид тензора напряжений (б), определяемый значениями коэффициента Лоде - Надаи, по результатам новой реконструкции.

На диаграмме в нижней части рисунков показана представительность определений соответствующих значений каждого из параметров.

Fig. 10. The geodynamic type of the state of stresses $(a)$ and the stress tensor (б) determined by values of the Lode - Nadai coefficient according to the new reconstructions.

In the diagram at the bottom of the figure, representativeness of determined values of each parameter is shown. 


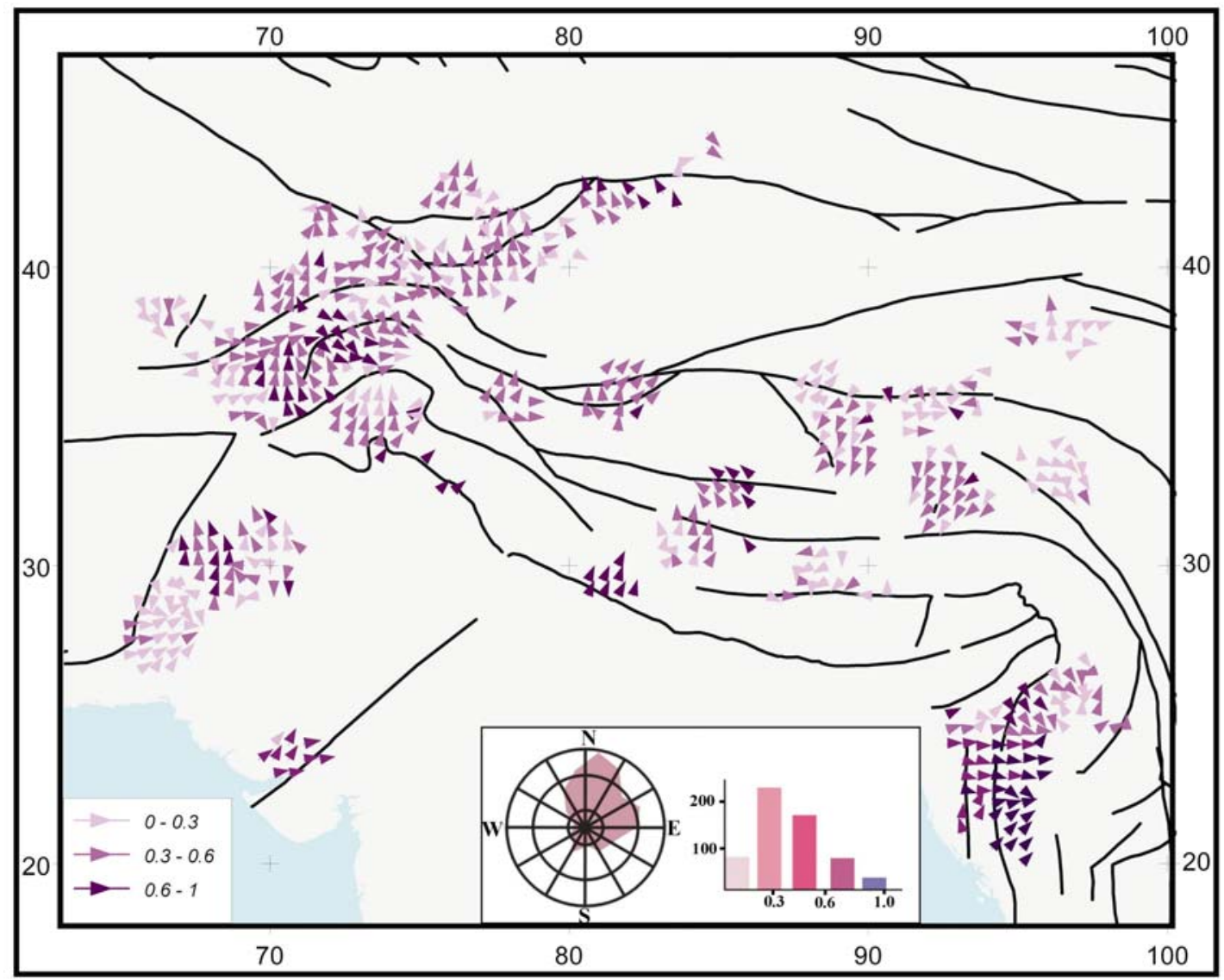

Рис. 11. Ориентация поддвиговых касательных напряжений на горизонтальных площадках и их относительные значения (нормировка на модуль максимального касательного напряжения) по результатам новой реконструкции.

В нижней части рисунка показана роза-диаграмма простираний осей поддвиговых касательных напряжений и диаграмма представительности различного уровня поддвиговых касательных напряжений.

Fig. 11. Orientations of underthrusting shear stresses over the horizontal planes and their relative values (normalized to the maximum tangential stress module) according to the new reconstructions.

In the diagrams at the bottom of the figure, strikes of the underthrusting shear stresses and representativeness of various levels of the tangential stresses of subduction are shown.

в новой реконструкции выглядит более упорядоченной, хотя для коры Памира она меняется от северозападной до юго-восточной.

Из роза-диаграммы рис. 11 видно, что преимущественным направлением действия поддвиговых касательных напряжений является субмеридиональное на север - северо-восток. Как выше уже было отмечено, основной вклад в него вносят области коры Памира, Тянь-Шаня, Куньлуня и Гималаев.

На втором этапе МКА производится расчет редуцированных значений максимальных касательных напряжений и эффективного всестороннего давления (разность между тектоническим давлением и давлением флюида в трещинно-поровом пространстве) [Rebetsky, 2003, 2005, 2009a, 2009b; Rebetsky et al., 2012; Rebetsky, Tatevossian, 2013]. Здесь на диаграмме Мора для каждого домена реконструкции напряжений анализируются расположения точек, характеризующих напряжения на плоскости очага землетрясений (рис. 12). Подобный анализ выполняется по данным однородной выборки землетрясений, отвечающей каждому домену. При этом в алгоритме МКА существует критерий выбора одной из нодальных плоскостей в качестве очага землетрясения. Этот критерий опирается на положение о близости точки, характеризующей напряжения на плоскости разрушения, плоскостям скалывания горных пород (касательная к большому кругу Мора на рис. 12).

На втором этапе МКА анализируется распределение точек на диаграмме Мора для каждой однородной выборки механизмов очагов землетрясений. Считается, что эти точки должны располагаться в полосе разрушения (область светло-серой заливки на рис. 12), отсекаемой внутри большого и снаружи малых кругов Мора (область возможных напряженных состояний на произвольно ориентированных плоскостях) линией 


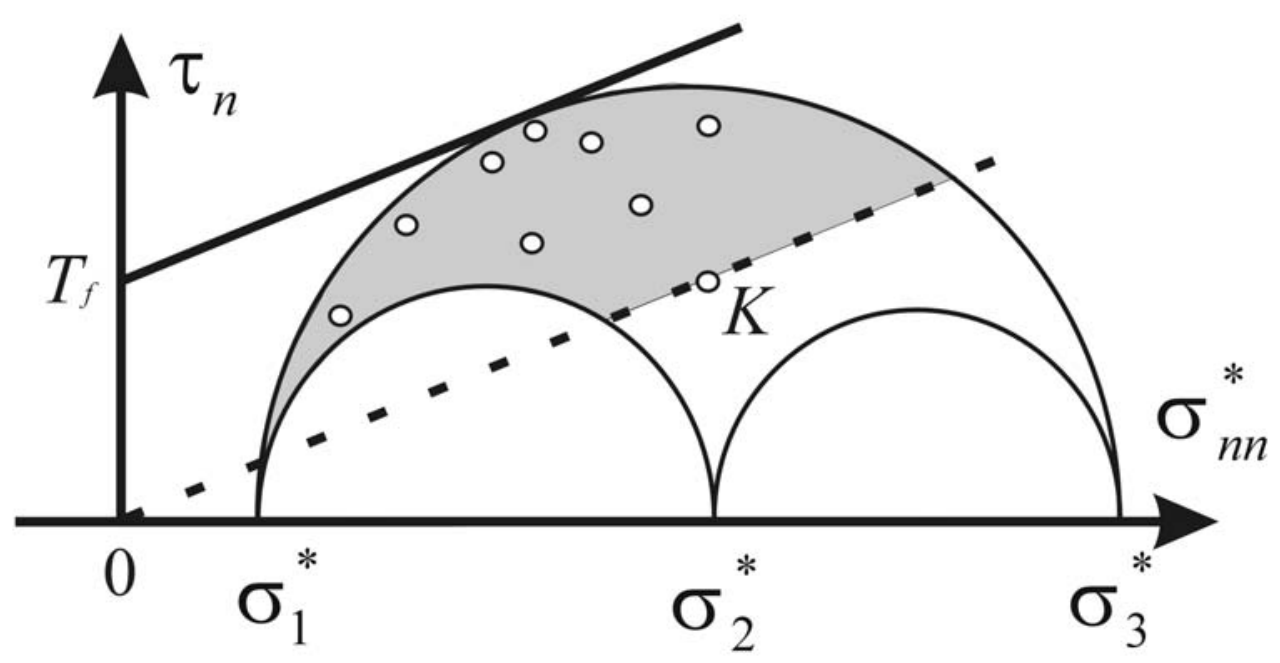

Рис. 12. Полоса разрушения и распределения точек с данными о напряжениях в очагах землетрясений из однородных выборок на диаграмме Mopa [Rebetsky, 2007a].

Точка К определяет положение линии минимального сопротивления сухого трения без сцепления (пунктир), сплошная линия - предел прочности пород с величиной внутреннего сцепления $T_{f}$.

Fig. 12. The band of destruction and distribution of points with data on stresses in earthquake foci from the homogeneous data sets in the Mohr diagram [Rebetsky, 2007a].

Point $\mathrm{K}$ determines the position of the line of the minimum dry friction resistance without cohesion (dashed line). The solid line shows the yield strength of rocks with the magnitude of internal cohesion.

минимального сопротивления кулонового трения. При этом предполагается, что все анализируемые напряженные состояния являются предельными, т.е. их большие круги Мора касаются линии предела внутренней прочности. Также считается, что предел внутренней прочности можно представить линией на диаграмме Мора, параллельной линии минимального сопротивления поверхностного статического трения. На основе этого анализа осуществляется оценка величин напряжений, определяемых с точностью до неизвестного значения внутреннего сцепления массивов горных пород, т.е. рассчитываются напряжения, редуцированные на неизвестное значение внутреннего сцепления $T_{f}$.

Определение величин напряжений и прочности $\left(T_{f}\right)$ в MKA производится на третьем и четвертом этапах метода. В настоящей работе будут представлены результаты расчета напряжений по алгоритму MKA только первых двух его этапов.

На рис. 13, $a$, показаны относительные значения эффективного всестороннего давления $p^{*}=p-p_{f l}$ (всестороннее тектоническое давление минус флюидное давление), нормировано на величину неизвестного внутреннего сцепления горных пород $\left(T_{f}\right)$ [Rebetsky, 2007a]. Напомним, что согласно экспериментальным данным и теории хрупкой прочности горных пород уровень эффективного давления определяет и уровень девиаторных напряжений, которые горная порода спо- собна выдержать без разрушения (см. рис. 12), поэтому участкам коры пониженного эффективного давления $p^{*}$ отвечают и пониженные значения максимального касательного напряжения $\tau$. Соответственно там, где в коре $p^{*}$ имеет повышенные значения, существует и повышенный уровень $\tau$. На рис. $13, a$, на врезке представлена диаграмма, определяющая взаимосвязь $p^{*}$ и $\tau$ в доменах коры, для которых в результате реконструкции получены данные о напряжениях.

Из данных рис. 13, $а$, видно, что кора Северного Тянь-Шаня испытывает высокий уровень эффективного давления $\left(p^{*} / T_{f}>10\right)$. Этот участок коры характеризуется геодинамическим режимом горизонтального сжатия (см. рис. 10, a), здесь главное напряжение максимального сжатия и промежуточное главное напряжение субгоризонтальны (напряжение наименьшего сжатия $\sigma_{1}$ субвертикально). Таким образом, для этого участка коры между полученным относительным уровнем эффективного давления и ориентациями главных осей напряжений устанавливается вполне прогнозируемая взаимосвязь.

Совершенно иная ситуация наблюдается в коре южной части Тянь-Шаня, Памира и его ближайшего окружения. Согласно данным рис. 12, а, здесь широко представлены области пониженного эффективного давления $\left(p^{*} / T_{f}<10\right)$. Заметим, что именно в коре Южного Тянь-Шаня и окружения Памира, согласно данным рис. $10, a$, действует геодинамический режим 

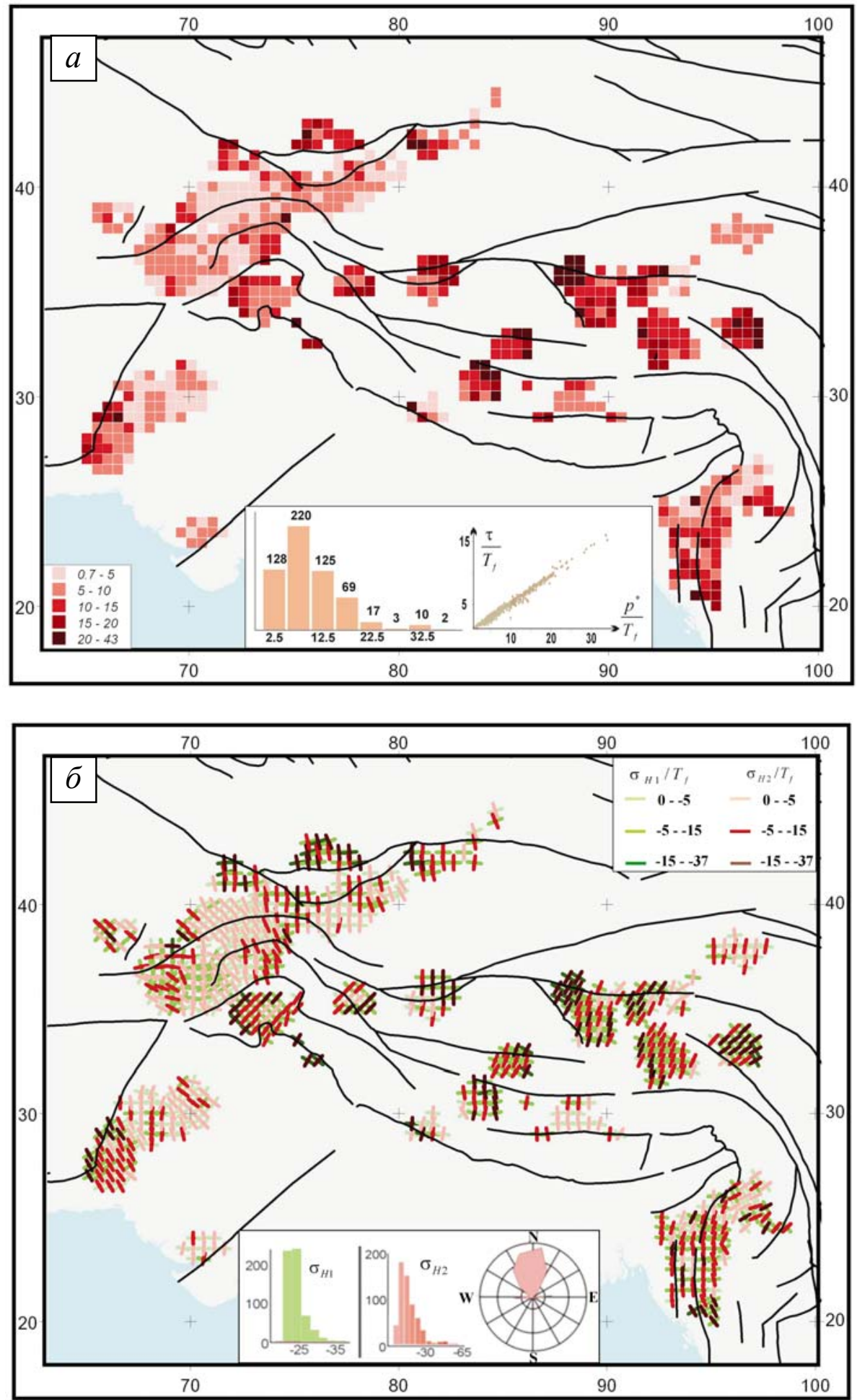

Рис. 13. Величины редуцированных значений эффективного давления (a), а также максимального (красные тона) и минимального (зеленые тона) сжатия (б), действующих в горизонтальном направлении, и ориентация этих осей по результатам реконструкции напряжений, выполненной в данной работе.

В нижней части рисунков показаны прямоугольные диаграммы распределения числа доменов с разными значениями редуцированного эффективного давления (a) и латеральных напряжений (б), диаграмма соотношения нормированных значений максимальных касательных напряжений и эффективного давления ( $a$ ), роза-диаграмма простирания осей максимального горизонтального сжатия (б).

Fig. 13. Values of reduced effective pressure (a), maximum (shade of red) and minimum (shade of green) compression (б) operating in the horizontal direction, and orientation of axes according to stress reconstructions in the present study.

At the bottom of the figures: rectangular diagrams showing distribution of numbers of domains with different values of reduced effective pressure (a) and lateral stresses (б), the diagram showing correlation between normalized ratio values of maximum shear stresses and effective pressure (a), and the rose diagram showing strikes of maximum horizontal compression axes (б). 
горизонтального сжатия. В поле значений эффективного давления Памир, в коре которого выделяются режимы горизонтального сдвига и горизонтального растяжения, не выглядит менее интенсивно сжатым, чем кора его окружения. Скорее наоборот, в коре его южной части, отвечающей режиму горизонтального растяжения, уровень эффективного давления выше.

Таким образом, из проведенного анализа следует, что геодинамический режим горизонтального сжатия прямо не определяет повышенный уровень девиаторных напряжений и эффективного давления, действующих в коре. Итак, мы обнаружили первое противоречие с теорией тектоники литосферных плит, определяющей именно горизонтальные напряжения в качестве основного фактора, влияющего на уровень девиаторных напряжений внутри континентальной коры.

Если продолжить наш анализ закономерности распределения эффективного давления в коре Высокой Азии, то, согласно данным рис. $13, a$, наиболее обширные области повышенного эффективного давления выделяются в коре Тибетского плато, там, где существует геодинамический режим горизонтального растяжения и горизонтального сдвига. Заметим, что области горизонтального растяжения расположены ближе к Индийскому индентору, и лишь в восточной и северной части коры Тибета режим горизонтального сдвига представлен повсеместно. Кора Гималаев значительно меньше представлена в результатах новой реконструкции, чем это было сделано в расчетах [Rebetsky et al., 1997], поэтому здесь мы имеем данные только для двух небольших участков коры Западных Гималаев вблизи Гиндукуша и в Центральных Гималаях (в коре Центральных Гималаев соседствуют участки повышенного и низкого уровня эффективного давления). Можно сказать, что для них наблюдается повышенный уровень эффективного давления при геодинамическом режиме горизонтального сжатия.

Таким образом, кора центральной части Тибетского плато и, возможно, Гималаев характеризуется наибольшим уровнем девиаторных напряжений при существенно разных действующих здесь геодинамических режимах. Этот факт сложно объяснить с позиции активного источника горообразования в виде давления Индийской плиты.

Если принять в качестве прочности внутреннего сцепления $T_{f}=6 \mathrm{MПа} \mathrm{(такое} \mathrm{значение} \mathrm{этого} \mathrm{параметра}$ было получено для коры Алтая и Саян в работах [Rebetsky et al., 2013; Rebetsky, Pogorelov, 2013]), то наиболее представительными для коры Высокой Азии будут значения эффективного давления 45 МПа, а верхний их уровень будет определяться значениями порядка 200 МПа. Согласно практическим результатам реконструкции напряжений в областях подготовки сильных землетрясений, выполненной в предыдущие годы [Rebetsky, Marinin, 2006a, 2006b; Rebetsky, 2009a, 2009b; Rebetsky, Tatevossian, 2013], областям, опасным с точки зрения развития крупномасштабного разруше- ния, отвечают участки коровых разломов, вдоль которых выделяются протяженные области пониженного эффективного давления, и при этом данные участки ограничены хотя бы с одной стороны зоной повышенного эффективного давления. Зона высокого градиента напряжений представляет собой участок разлома, где зарождается землетрясение. Распространение очага идет в направлении области пониженного эффективного давления. С этих позиций разломная зона северозападного фланга Памира (рис. 13, a) представляет собой наиболее опасную область для формирования сильного землетрясения. Протяженность области пониженного эффективного давления здесь порядка 200$250 \mathrm{kм}$, что говорит о возможности возникновения землетрясения с магнитудой около 8. Этот вывод следует рассматривать как сугубо предварительный, его необходимо проверять более детальными исследованиями, используя современные региональные сейсмические каталоги Казахстана, Кыргызстана.

На рис. 13, б, показана ориентация осей напряжений максимального и минимального сжатия, действующих в горизонтальном направлении. Направления осей этих напряжений легко получить, построив горизонтальное сечение эллипсоида напряжений. Относительные величины этих напряжений (нормировка на $T_{f}$ ) получены в результате применения алгоритма второго этапа МКА.

Как видно из этого рисунка, наибольшие величины латерального сжатия испытывает кора Тянь-Шаня и Северо-Восточного Тибета. Напомним, что в большинстве этих областей имеет место геодинамический тип напряженного состояния горизонтального растяжения, т.е. здесь максимальное сжатие ориентировано субвертикально. В коре Южного Тибета, ближе к Гималаям, уровень латерального сжатия ниже, чем в указанных областях. Наиболее низкий уровень латерального сжатия, занимающий достаточно большие площади, наблюдается в коре Памира, северо-западного обрамления Таримской плиты и в северо-восточной части коры Тибета. Промежуточный уровень этих напряжений действует в коре Афганского поднятия и синтаксисе Намче Барва.

В коре Гималаев имеется только несколько определений параметров тензора напряжений для западного и центрального участков. Здесь наблюдается повышенный уровень латерального сжатия.

Согласно суммирующей роза-диаграмме, приведенной на рис. 13, оси максимального латерального сжатия ориентированы в большинстве на север - северозапад, субмеридионально и на север-северо-восток. Заметим, что разворот псевдоглавных осей латерального сжатия наблюдается для коры синтаксиса Намче Барва в соответствии с изменяющейся ориентацией разломов. В коре Памира и Гиндукуша наблюдается блочная картина в ориентации этих осей. Здесь существуют 4-5 блоков с ориентацией осей латерального сжатия, отличающейся на $30-40^{\circ}$. 


\section{6. ОБСУЖДЕНИЕ РЕЗУЛЬТАТОВ РЕКОНСТРУКЦИИ ПО ДВУМ КАТАЛОГАМ}

Результаты реконструкции современного напряженного состояния, выполненной по двум разным каталогам механизмов очагов землетрясений, показали, что в них присутствует большое число участков коры, имеющих одинаковые или близкие параметры напряженного состояния. Однако находятся отдельные участки коры, где данные о напряжениях противоречат друг другу. Так, резко отличающаяся ориентация осей максимального сжатия наблюдается в коре центральной части Тибетского плато (см. рис. 4, б, и рис. 9, в), а осей максимального девиаторного растяжения - в коре Восточного Тянь-Шаня, Гиндукуша и западной части Памира. Подобные изменения ориентации осей главных напряжений привели к появлению в результатах реконструкции по каталогу 1978-2010 гг. обширной области геодинамического режима горизонтального растяжения в коре центральной части Тибета (см. рис. $10, a)$, в то время как в реконструкции по каталогу 1904-1992 гг. здесь наблюдалась область горизонтального сдвига (см. рис. 5, a). Более ярко в реконструкции по каталогу 1978-2010 гг. проявился геодинамический режим горизонтального растяжения для коры Памира и Гиндукуша, находящийся в окружении режима горизонтального сжатия.

Полученные разночтения в результатах реконструкции напряжений требуют объяснения. Мы их связываем с двумя факторами. Во-первых, с тем, что при построении механизма очага землетрясения в виде двойного диполя на основе анализа знаков первых вступлений продольной волны может иметь место несоответствие его характеристик и магнитуды события (это выше уже было отмечено). В то же время механизмы, полученные на основе анализа общей волновой картины, отвечают фазе сильных движений в очаге. Если с этих позиций интерпретировать различия в напряженном состоянии обеих реконструкций, то тогда можно говорить о существенной зависимости характера напряженного состояния от масштабного фактора и об иерархичности напряжений выделенных участков коры.

Второй причиной разночтений двух реконструкций является неоднозначность определений механизмов очагов землетрясений, проявившаяся в каталоге 19041992 гг., где одному и тому же землетрясению могли отвечать достаточно сильно различающиеся механизмы, полученные разными авторами по разным региональным сейсмическим сетям, окружающим эпицентр землетрясения. Методика расчета напряжений, примененная к таким данным, позволяла выполнять реконструкцию и в этом случае. Систематические различия в механизмах очагов, полученных по данным разных региональных сейсмических сетей, могут быть связаны с односторонним окружением эпицентра землетрясения и высокой раздробленностью данных участков коры. Таким образом, здесь на результат расчетов напряжений могут влиять ошибки определения механизмов, фактически характеризующие сложность строения участков коры.

Выполненный сравнительный анализ результатов двух реконструкций показывает, что, несмотря на отдельные различия, в них наблюдается хорошая преемственность. В то же время исходные для реконструкции напряжений каталоги механизмов очагов землетрясений не равнозначны. Более достоверным является каталог механизмов очагов землетрясений в виде двойного диполя Global CMT (механизмы очагов по общей волновой картине) для временного периода 1978-2010 гг., поэтому предлагается для тех участков коры, где имеются результаты реконструкции напряжений по данному каталогу, использовать их в качестве наиболее достоверных. Там, где данных расчетов по этому каталогу нет, но есть результаты расчетов напряжений по каталогу 1904-1992 гг. (механизмы очагов по данным о первых вступлениях), следует использовать эти данные.

На основе применения предложенного приоритета достоверности результатов этих двух реконструкций, на рис. 14 представлены карты, суммирующие некоторые параметры напряженного состояния коры Высокой Азии. Как видно из рис. 14, а, дополнение данных об ориентации осей максимального сжатия, полученных по механизмам очагов землетрясений каталога 1978-2010 гг., результатами реконструкции 1997 г. практически везде дает хорошее согласие. Дополнительные данные существенно увеличивают область знания об ориентации этих осей. Вопросы возникают в отношении некоторого числа доменов с субгоризонтальной ориентацией осей $\sigma_{3}$ в коре южной части Тибета, рассекающих области с крутопогруженных осей $\sigma_{3}$ новой реконструкции 1978-2010 гг. Анализ геодинамического типа напряженного состояния (рис. 14, б) показывает, что эти домены имеют состояние горизонтального сдвига, который в результатах новой реконструкции здесь также присутствует, правда в областях, расположенных несколько восточнее и севернее.

Обратим внимание, что на карте суммарных напряженных состояний по их геодинамическому типу кора Тибета в центральном и южном его сегментах, в Восточном Куньлуне к югу от Западного Куньлуня широко представлена доменами горизонтального растяжения. В коре самого Западного Куньлуня имеет место сочетание горизонтального растяжения со сдвигом. Таким образом, режим горизонтального растяжения присутствует в коре Тибете везде до Цайдамской впадины на севере, до Гималаев на юге и до $95^{\circ}$ в.д. на востоке. На западе этот тип напряженного состояния включает в себя также южную часть коры Памира. В коре Тибета западнее $90^{\circ}$ в.д. практически повсеместно присутствует горизонтальный сдвиг, а в коре Циалин Шаня и Нань Шаня имеет место горизонтальное сжатие. 

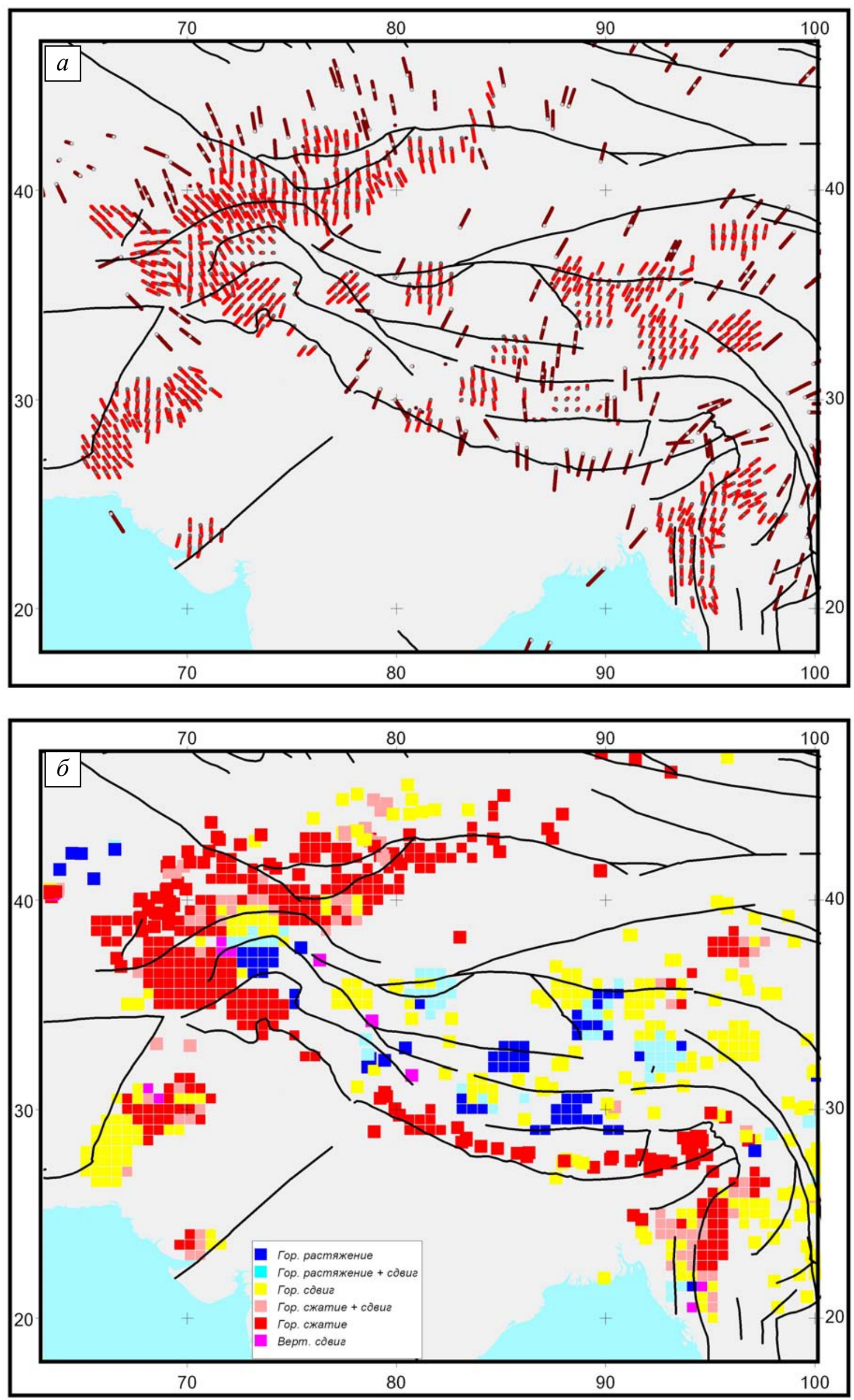


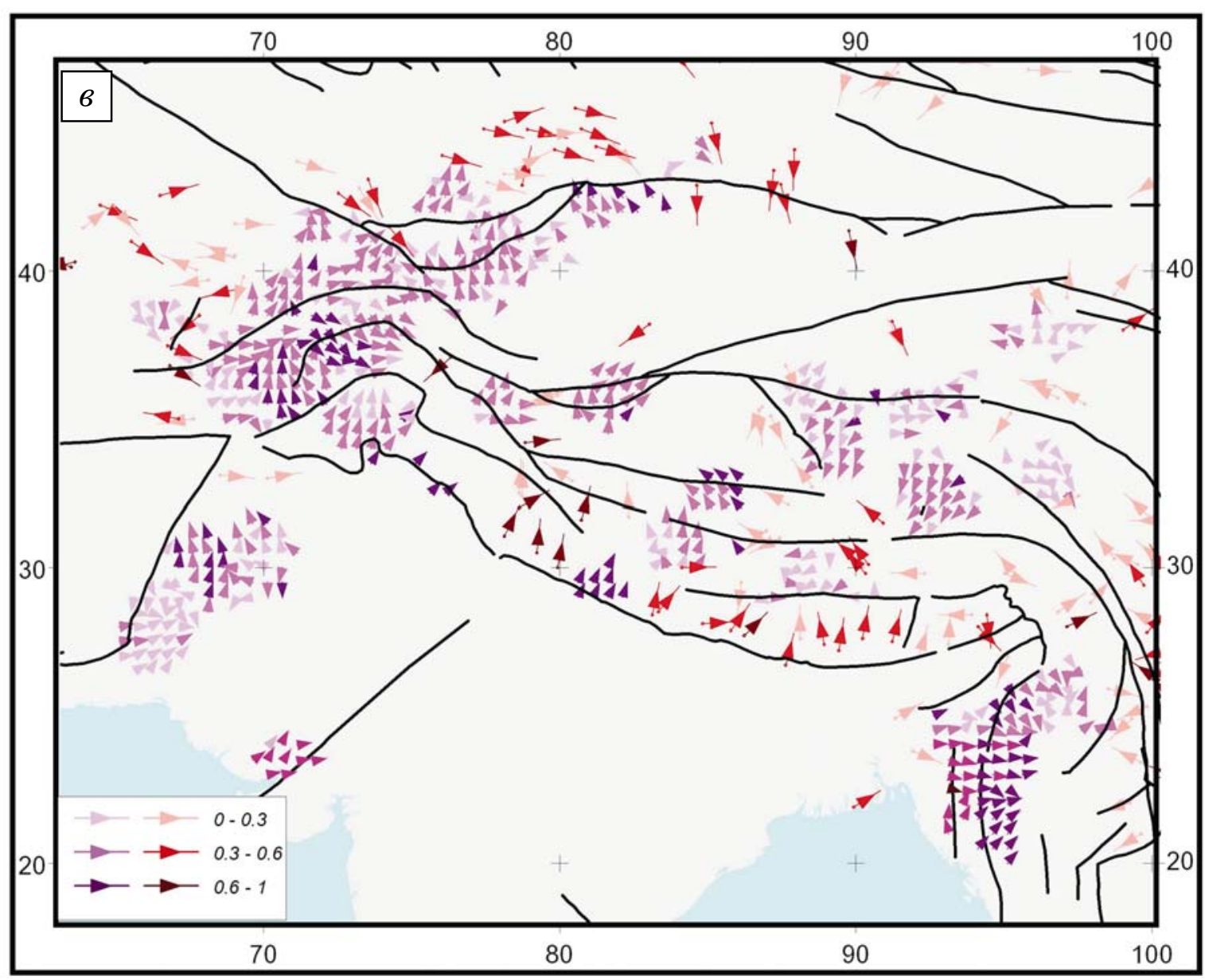

Рис. 14. Параметры тензора напряжений, полученные путем суммирования двух реконструкций: $a$ - проекции на горизонтальную плоскость осей погружения напряжений максимального сжатия (векторы красного цвета отвечают реконструкции напряжений, выполненной в данной работе (2013 г.), а темно коричневые - 1997 г. [Rebetsky et al., 1997]); б - геодинамический тип напряженного состояния (квадраты большего размера отвечают реконструкции 1997 г.); в - поддвиговые касательные напряжения (стрелки красных оттенков отвечают реконструкции 2013 г., фиолетовые - 1997 г.).

Fig. 14. Parameters of the stress tensor obtained by summing the two reconstructions: $a$ - projections to the horizontal plane of dip axes of maximum compression stresses (red vectors - stress reconstructions in the present study (2013); dark brown vectors - stress reconstructions in [Rebetsky et al., 1997]); $\sigma$ - geodynamic types of the state of stresses (big squares - stress reconstructions obtained in 1997; 8 - underthrusting shear stresses (red arrows - stress reconstructions obtained in 2013; purple arrows - stress reconstructions obtained in 1997).

Анализируя выявленную обстановку горизонтального растяжения в коре Тибетского плато, отметим, что это отвечает геологическим данным, показывающим наличие в южной и западной части коры грабенов меридиональной ориентации, а в центральной части коры - разрывов сбросо-сдвигового типа широтной и северо-западной ориентации [Milanovsky, 1991; Molnar, Tapponnier, 1978]. Все это хорошо согласуется с данными о современном напряженном состоянии коры региона.

Смена геодинамического режима горизонтального растяжения в пределах Тибетского плато к северу от Восточного Куньлуня и к востоку от $95^{\circ}$ в.д. происходит постепенно через режим горизонтального сдвига. На юге подобная смена режима происходит резко. В коре Гималаев повсеместно расположены домены горизонтального сжатия. Здесь очень хорошо сочетаются результаты обеих реконструкций.

Кора Высокого Памира, испытывающего обстановку растяжения (южная часть) и сдвига (северная часть), так же как и кора плато Тибета, окружена областями, находящимися в состоянии горизонтального сжатия. Отметим, что восточнее, в коре Афганской впадины, также наблюдается обстановка горизонтального растяжения.

На рис. 14, в, представлены результаты суммирования обеих реконструкций для поддвиговых касательных напряжений, действующих на горизонтальных площадках, нормали к которым направлены в глубь Земли. Здесь прежде всего выделим полосу коры, от- 
вечающую Гималаям, где повсеместно векторы этих напряжений направлены от Индийской плиты на северо-восток. В коре западной части Тибета эта ориентация поддвиговых касательных напряжений прослеживается вплоть до южных границ Таримской плиты, в коре восточной части Тибета севернее $30^{\circ}$ с.ш. наблюдается обратная ориентация этих касательных напряжений.

Таким образом, суммарные карты напряженного состояния коры Высокой Азии дают достаточно целостную картину собственной роли высокогорных орогенов. Памир, который в центральной части имеет достаточно плоский рельеф без высоких пиков, и плато Тибета имеют особенность напряженного состояния, близкую к центрально-симметрическому типу. В эту концепцию встраивается и наличие областей повышенного эффективного давления и латерального сжатия в коре центральной части Тибета (см. рис. 13), и характер разломной тектоники Памира, и форма границ Тибета.

В начале статьи мы представили спектр работ по изучению современного напряженного состояния коры Высокой Азии другими исследователями. В большинстве этих работ не было выявлено главного элемента обширного геодинамического режима горизонтального растяжения в коре Тибетского плато. Это прежде всего относится к работам [Zobak, 1992; Coblentz, Richardson, 1995; Trifonov et al., 2002; Heidbach et al., 2007, 2008, 2010]. В них для коры Тибетского плато практически везде показана субгоризонтальная ориентация осей максимального сжатия. Это связано либо с использованием данных только о сильных землетрясениях $\left(M_{b} \geq 7\right)$ [Zobak, 1992; Coblentz, Richardson, 1995], либо с проблемами усреднения и интерполяции [Heidbach et al., 2007, 2008, 2010].

В работе [Trifonov et al., 2002] для коры Западного Куньлуня и для нескольких точек коры Памира получены области горизонтального растяжения, но для коры Тибета здесь приводится режим горизонтального сжатия и горизонтального сдвига. Вероятно, это связано с большими окнами горизонтального усреднения при расчете тензора сейсмотектонических деформаций и ролью отдельных сильных землетрясений в его параметрах. В исследованиях, выполненных в работе [Koptev et al., 2011], кора Тибета и Памира представлена пятью точками с данными о «напряженном состоянии». Они отвечают горизонтальному растяжению (три точки) и горизонтальному сдвигу с растяжением (две точки).

На картах из работы [Sherman, Lunina, 2001] для южной части коры Тибета показан геодинамический тип напряженного состояния горизонтального сдвига с растяжением, а для небольшой площади юго-восточной части коры - чистое горизонтальное растяжение. Это с определенной оговоркой похоже на полученный в нашей работе результат. Но на этой карте кора Памира представлена режимом горизонтального сжатия со сдвигом, что не отвечает результатам нашей реконструкции.

В работе [Kuchai, Bushenkova, 2009] в результате только анализа механизмов очагов землетрясений в чистом виде для коры Тибета и Памира были выявлены области, отвечающие чисто сбросовым механизмам и сбросам со сдвигами. Но здесь не производилось площадное картирование геодинамических типов напряженного состояния, поэтому сложно сказать, насколько площади режимов горизонтального растяжения, выявленные в этой работе, совпадают с областями, полученными в наших исследованиях.

В исследованиях [Petrov et al., 2008] также получены данные о наличии в коре западного сектора Тибета горизонтального растяжения. Основные же области коры Тибета здесь представлены геодинамическим типом напряженного состояния в виде горизонтального сжатия со сдвигом и октаэдрическим типом (ось на зенит равноудалена от всех осей главных напряжений). Коре Памира в этой реконструкции в основном отвечает октаэдрический геодинамический тип напряженного состояния. Такие отличия в результатах от наших данных связаны не с особенностями используемого в работе [Petrov et al., 2008] метода, а с разным типом исходных данных в виде каталога механизмов очагов землетрясений. В этой работе ее авторы выполнили самостоятельный анализ знаков первых вступлений в $P$-волне при создании своего каталога.

В любом случае, в результатах анализа напряженного состояния коры Высокой Азии указанных выше авторов фигурируют только ориентации главных осей и типы геодинамических режимов. Эти параметры тензора напряжений в наших исследованиях являются лишь одним из аргументов в пользу модели напряженного состояния с центром симметрии в центральной части Тибета. Два других параметра - распределение поддвиговых касательных напряжений на горизонтальных площадках и площадное распределение эффективного давления и редуцированных латеральных напряжений - в этих работах не рассматривались (последний параметр в них не может быть даже определен).

\section{7. Выводы}

Результаты реконструкции современных напряжений в коре Высокой Азии, выполненной в настоящей работе, с одной стороны, подтвердили представления о роли Индийской литосферной плиты. Это, в частности, отражает близкое к радиально-концентрическому распределение ориентации осей латерального максимального и минимального сжатия, соответственно, «разбегающихся» от Гималаев. Здесь следует заметить, что данная ориентация лучше прослеживается в результатах реконструкции по данным каталога 1904-1992 гг. (см. рис. 4), чем каталога 1978-2010 гг. (см. рис. 9). Об 
этом же говорит ориентация поддвиговых касательных напряжений на горизонтальных площадках, действующих в коре Гималаев. Они ориентируются на север северо-восток, определяя ведущую роль подкоровой мантии в соответствующем движении Индийского индентора.

Как уже отмечалось выше, возможна двойная интерпретация данных о поддвиговых касательных напряжениях. В первой активным источником подобного напряженного состояния является мантия, двигающаяся из-под Индийской плиты на северо-восток; во второй активным источником является кора Тибетского плато, которая, надвигаясь на Гималаи, смещает его кору относительно мантии на юго-запад. Оба этих варианта интерпретации не противоречат известным данным GPS-геодезии [Zubovich et al., 2007], если трактовать их как относительные перемещения, возникающие в первом случае в предположении стабильной Сибирской платформы, а во втором для стабильного Тибетского плато. В этом случае скорость движения Индийской плиты на север-северо-восток будет составлять порядка 15-20 мм/год, а скорость движения Сибирской пластформы на юг - юго-восток будет около 25 мм/год.

В пользу второго варианта интерпретации говорит и анализ общей картины направлений действия касательных напряжений на горизонтальных площадках (рис. 14, в). Он показывает, что для коры Тибета эти напряжения ориентируются от периферии к центру. Данной обстановке вполне отвечает интерпретация, определяющая механизм растекания утолщенной коры высокого Тибетского плато [Artyushkov, 1972]. С севера это растекание сдерживается движением на север-северо-восток Индийской плиты. Между этой плитой и надвигающимися на нее горными массивами Тибета возникает область интенсивного раздавливания, формирующего Гималаи, которые, как известно, не имеют корней в низах коры [Kunin et al., 1988]. Coгласно работе [Pogrebnoi, Sabitova, 2001], в мантии под Тибетом имеется крупный мантийный плюм, который, с одной стороны, может рассматриваться как источник, определивший изменение механических свойств горных пород литосферы, а с другой - говорить о длительности расположения Тибета в данной области. Если бы движение на север-северо-восток Индийской плиты происходило со скоростью около 40 мм/год, как это имеет место в предположении стабильной Сибирской платформы, то за 45 млн лет смещение в этом направлении плато Тибета должно было составлять около 1800 км. Т.е. южная граница Тибета в момент начала коллизии должна была бы находиться на $15^{\circ}$ с.ш., а сам Тибет не располагался бы над длительно действующим мантийным плюмом.

Пожалуй, наиболее весомо в пользу этой гипотезы говорит напряженное состояние центральной части коры Тибета, где наблюдается режим горизонтального растяжения (рис. 14, б) с субвертикальной ориентаци- ей осей максимального сжатия (рис. 14, a). На рис. 8 видно, что для коры Тибета имеется достаточно большое число решений механизмов очагов землетрясений средней силы (магнитуды, близкие к 6) сбросового типа. Это отмечалось также в работе [Kuchai, Bushenkova, 2009]. Отметим, что кора Тибета с севера и юга окружена корой, в которой превалирует режим горизонтального сжатия.

Также режим горизонтального растяжения и его сочетание со сдвигом получены и для коры Памира (см. рис. 10, a). Здесь результаты обеих реконструкций совпадают (см. рис. 5, a). К северо-востоку и юго-западу от коры Памира наблюдаются обширные участки коры с режимом горизонтального сжатия. Подобную ситуацию, когда в коре соседствуют два диаметрально противоположных геодинамических режима (горизонтальное сжатие и растяжение), следует анализировать, добавляя вполне логичное требование равенства сил, действующих в латеральном направлении. Из этого анализа следует, что напряжение максимального сжатия, действующее вертикально в коре Высокого Памира, больше, чем напряжение максимального сжатия, действующее горизонтально в коре его ближайшего окружения. Этот факт означает, что горизонтальное сжатие не является фактором, обеспечивающим современное поднятое состояние Памира.

Тот же анализ можно провести и для коры Тибета, где наиболее представлен режим горизонтального растяжения и горизонтального сдвига. В коре Гималаев, отделяющей Тибет от Индийской плиты, наблюдается режим горизонтального сжатия. Большее по величине вертикальное сжатие в коре Тибета следует рассматривать как активное усилие, а напряжения, действующие в горизонтальном направлении, как реактивные силы. Эти горизонтальные реактивные силы должны уравновешиваться коровыми горизонтальными напряжениями со стороны Гималаев. Согласно данным современного напряженного состояния, горные области Гималаев выглядят как область выдавливания вверх коры между жесткой Индийской плитой и наваливающимися на нее с севера горными массами Тибетского плато. На севере, где нет мощного сдерживающего фактора для растекания коры Тибета, действует меньший уровень горизонтального сжатия в северовосточном направлении (см. рис. 13, б). Выполненная нами трактовка геодинамического режима коры Высокой Азии согласуется с представлениями о большой роли в формировании современного поля напряжений областей поднятий и находящейся под ними разогретой мантии [Logatchev, Zorin, 1987], определяя в качестве основного механизма генерации напряжений латеральное растекание высокогорных плато Тибета и Центрального Памира под действием гравитационных сил [Artyushkov, 1972].

Отметим, что в наших последних исследованиях современного напряженного состояния коры горноскладчатых орогенов Центральной Азии (Северный 
Тянь-Шань и Алтае-Саяны) [Rebetsky, 2012a, 2012b; Rebetsky et al., 2012; Rebetsky et al., 2013; Rebetsky, Pogorelov, 2013; Rebetsky, Tatevossian, 2013] показано, что в большинстве случаев (65-75\%) в коре горных поднятий действует геодинамический режим горизонтального сжатия. В то же время в рядом расположенных участках коры прогибов в большинстве случаев наблюдается режим горизонтального растяжения. В работах [Rebetsky, 2012a, 2012b; Rebetsky et al., 2013; Rebetsky, Pogorelov, 2013] делается предположение, что эти режимы длительное время рядом сосуществуют из-за внутрикорового течения, объединяющего напряженное состояние этих двух динамо-пар в единый механизм деформирования, и процессов денудации горных поднятий и осадконакопления в областях прогибов. Вероятно, подобная ситуация возникает в коре для стадии активно развивающихся орогенов, когда несмотря на нивелирующее действие экзогенных процессов идет интенсивный рост амплитуд рельефа. В случае, когда континентальный ороген находится в завершающей стадии своего состояния, т.е. при выравнивании рельефа его поверхности, эта выявленная за- кономерность напряженного состояния не работает. Здесь действует иной характер внутрикорового течения, которое определяет геодинамические режимы коры. Эти изменения должны начинаться с центральных частей орогенов и распространяться к периферии, что мы и наблюдаем для коры Тибетского плато и Памира.

Таким образом, заключаем, что результаты реконструкции напряжений в коре Высокой Азии дали возможность увидеть ряд его особенностей, которые не позволяют трактовать механизм их генерации однозначно с позиции тектоники литосферных плит. Выявленные закономерности напряженного состояния коры Тибета и его окружения вместе с ранее полученными данными о распределении напряжений в коре Северного Тянь-Шаня и Алтае-Саян требуют дополнительного анализа, в рамках которого следует привлекать результаты тектонофизического моделирования.

Работа выполнена при поддержке грантов по программе № 6 ОНЗ РАН, РФФИ № 13-05-00892а, № 1205-00234a, № 12-05-33066 вед_мол_а, № 12-05-00550, ФЦП «Научные и научно-педагогические кадры инновационной России», соглашение № 8615.

\section{8. ЛИТЕРАТУРА / REFERENCES}

Alekseev R.S., Rebetsky Yu.L., 2011. The tectonophysical field of recent stresses in Central Asia. In: Modern tectonophysics. Methods and results. Proceedings of the 2nd tectonophysical workshop held on 17-21 October 2011. IPE RAS, Moscow, p. 284-289 (in Russian) [Алексеев Р.С., Ребецкий Ю.Л. Тектоническое поле современных напряжений Средней Азии // Современная тектонофизика. Методы и результаты. Материалы Второй тектонофизической школысеминара 17-21 октября 2011 г. М.: ИФЗ РАН, 2011. С. 284-289].

Alekseev R.S., Rebetsky Yu.L., 2012. The tectonophysical field of recent stresses in the South-Eastern Asia. In: Tectonophysics and top issues of the Earth Sciences. Proceedings of the 3rd tectonophysical conference held in IPE RAS on Workshop held on 8-12 October 2012. IEP RAS, Moscow, p. 139-142 (in Russian) [Алексеев Р.С., Ребецкий Ю.Л. Тектоническое поле современных напряжений Юго-Восточной Азии // Тектонофизика и актуальные вопросы наук о Земле. Третья тектонофизическая конференция в ИФЗ РАН. Материалы докладов конференции 8-12 октября 2012 г. М.: ИФЗ РАН, 2012. С. 139-142].

Angelier J., 1989. From orientation to magnitude in paleostress determinations using fault slip data. Journal of Structural Geology 11 (1-2), 37-49. http://dx.doi.org/10.1016/0191-8141(89)90034-5.

Artyushkov E.V., 1972. The origin of large stresses in the Earth's crust. Izvestiya AN SSSR. Seriya Fizika Zemli (Izvestiya AN SSSR. Earth Physics Series) 8, 22-36 (in Russian) [Артюшков E.B. Происхождение больших напряжений в земной коре // Известия АН СССР. Серия Физика Земли. 1972. № 8. С. 22-36].

Balakina L.M., Zakharova A.I., Moskvina A.M., Chepkunas L.S., 1996. The regular relationship between earthquake focal mechanism and regional geological settings. Fizika Zemli 3, 33-52 (in Russian) [Балакина Л.М., Захарова А.И., Москвина А.М., Чепкунас Л.С. Закономерная связь механизмов очагов землетрясений с геологическими строениями районов // Физика Земли. 1996. № 3. С. 33-52].

Brace W.F., 1978. Volume changes during fracture and frictional sliding: A review. Pure and Applied Geophysics 116 (4-5), 603-614. http://dx.doi.org/10.1007/BF00876527.

Burtman V.S., 2012. The Tien Shan and the High Asia. Geodynamics in the Cenozoic. Geos, Moscow, 188 p. (in Russian) [Буртман В.С. Тянь-Шань и Высокая Азия. Геодинамика в кайнозое. М.: Геос, 2012. 188 с.].

Byerlee J.D., 1968. Brittle-ductile transition in rocks. Journal of Geophysical Research 73 (14), 4741-4750. http://dx.doi. org/10.1029/JB073i014p04741.

Byerlee J.D., 1978. Friction of Rocks. Pure and Applied Geophysics 116 (4-5), 615-626. http://dx.doi.org/10.1007/BF00876 528.

Catalogues of Earthquake Focal Mechanisms in China, 1980. 400 p. (in Chinese) [Каталог механизмов очагов землетрясений Китая. 1980. 400 с.

Coblentz D., Richardson R.M., 1995. Statistical trends in the intraplate stress field. Journal of Geophysical Research: Solid Earth 100 (B10), 20245-20255. http://dx.doi.org/10.1029/95JB02160. 
Dziewonski A.M. et al., 1977-1996. Centroid-moment tensor solutions for... Physics of Earth and Planetary Interiors.

Earthquakes in the USSR from 1964 to 1989. Nauka, Moscow, 1967-1992 (in Russian) [Землетрясения в СССР в 1964 ... 1989 гг. М.: Наука, 1967 ... 1992].

Gushchenko O.I., 1975. The kinematical principle of reconstruction of directions of major stresses (from geological and seismological data). Doklady AN SSSR 225 (3), 557-560 (in Russian) [Гущенко О.И. Кинематический принцип реконструкции направлений главных напряжений (по геологическим и сейсмологическим данным) // Доклады АН СССР. 1975. Т. 225. № 3. С. 557-560].

Gushchenko O.I., 1979. The method of kinematic analysis of destruction structures in reconstruction of tectonic stress fields. In: Fields of stress and strain in the lithosphere. Nauka, Moscow, 7-25 (in Russian) [Гущенко О.И. Метод кинематического анализа структур разрушения при реконструкции полей тектонических напряжений // Поля напряжений и деформаций в литосфере. М.: Наука, 1979. С. 7-25].

Gushchenko O.I., 1996. Seismotectonic stress monitoring of the lithosphere: the structural kinematic principle and basic features of the algorithm. Doklady Earth Sciences 346 (1), 144-147.

Gushchenko O.I., Mikhailova A.V., Nikitina E.S., Rebetsky Yu.L., Lomakin A.A., Arefieva T.P., 1994a. The recent crustal deformation mechanism in the Caucasus-Iran seismically active region according to regional stress monitoring data and tectonophysical modeling. In: Abstracts of Reports at the $1^{\text {st }}$ International Workshop on Stresses in the Lithosphere. IGiRGI Publishing House, Moscow, p. 49-50 (in Russian) [Гущенко О.И., Михайлова А.В., Никитина Е.С., Ребецкий Ю.Л., Ломакин А.А., Арефьева Т.П. Современный механизм деформирования земной коры Кавказо-Иранской сейсмоактивной области по данным регионального стресс-мониторинга и тектонофизического моделирования // Тезисы докладов первого международного семинара: Напряжения в литосфере (глобальные, региональные, локальные). М.: Издательство ИГиРГИ, 1994а. С. 49-50].

Gushchenko O.I., Mostryukov A.O., Petrov V.A., 1990. The structure of the recent stress field in seismically active regions of the crust in the eastern part of the Mediterranean mobile belt. Doklady AN SSSR 312 (4), 830-835 (in Russian) [Гущенко О.И., Мострюков А.О., Петров В.А. Структура поля современных напряжений сейсмоактивных областей земной коры восточной части Средиземноморского подвижного пояса // Доклады АН СССР. 1990. Т. 312. № 4. С. 830835].

Gushchenko O.I., Rebetsky Y.L, Michailova A.V., 1993. The recent regional field of stresses and the mechanism of the lithosphere deformation of seismoactive East-Asia region. In: Abstract supplement EUG VII. TERRA nova, Strasbourg, V. 5 (1), p. 259.

Gushchenko O.I., Rebetsky Yu.L., Mikhailova A.V., Rossanova G.V., Kuok L.M., Fursova E.V., 1994b. The recent regional field of stresses in Eurasia (from seismological data on crustal earthquake focal mechanisms. In: Abstracts of Reports at the 1st International workshop on stresses in the lithosphere. IGiRGI Publishing House, Moscow, p. 50-51 (in Russian) [Гущенко О.И., Ребецкий Ю.Л., Михайлова А.В., Россанова Г.В., Куок Л.М., Фурсова Е.В. Современное региональное поле напряжений Евразии (по сейсмологическим данным о механизмах очагов коровых землетрясений) // Тезисы докладов первого международного семинара: Напряжения в литосфере (глобальные, региональные, локальные). М.: Издательство ИГиРГИ, 1994b. С. 50-51].

Gushchenko O.I., Rebetsky Yu.L., Mikhailova A.V., Rossanova G.V., Lomakin A.A., Arefieva T.P., 1991. Regional stress monitoring and the crustal deformation mechanism in the Caucasus-Iran seismically active region. In: The mechanics of structure formation in the lithosphere and seismicity. IPE RAS, Moscow, p. 165-166 (in Russian) [Гущенко О.И., Ребецкий Ю.Л., Михайлова А.В., Россанова Г.В., Ломакин А.А., Арефьева Т.П. Региональный стресс-мониторинг и механизм деформирования земной коры Кавказо-Иранской сейсмоактивной области // Механика структурообразования в литосфере и сейсмичность. М.: ИФЗ РАН, 1991. С. 165-166].

Hardebeck J.L., Hauksson E., 2001. Crustal stress field in southern California and its implications for fault mechanics. Journal of Geophysical Research: Solid Earth 106 (B10), 21859-21882. http://dx.doi.org/10.1029/2001JB000292.

Heidbach O., Reinesker J., Tingay M., Muller B., Sperener B., Fuchs K., Wenzel F., 2007. Plate boundary forces are not enough: Second- and third-order stress pattern highlighted in the World Stress Map database. Tectonics 26 (6), TC6014. http://dx.doi.org/10.1029/2007/TC002133.

Heidbach O., Tingay M., Batrth A., Reinesker J., Kurfeb D., Muller B., 2008. The Word Stress Map. Commission for the Geological Map of the World. Release 2008. Paris.

Heidbach O., Tingay M., Batrth A., Reinesker J., Kurfeb D., Muller B., 2010. Global crustal stress pattern based on the Word Stress Map data base release 2008. Tectonophysics 482 (1-4), 3-15. http://dx.doi.org/10.1016/j.tecto.2009.07.023.

International tectonic map of the world. Scale: 1:15 000 000. Academy of Sciences of the USSR, Moscow, 1984.

Koptev A.I., Ershov A.V., Malovichko E.A., 2011. Interpolation and extrapolation of the World Stress Map data. In: Methods and results. Proceedings of the 2nd tectonophysical workshop held on 17-21 October 2011. IPE RAS, Moscow, p. 130138 (in Russian) [Коптев А.И., Ершов А.В., Маловичко Е.А. Интерполяция и экстраполяция данных «мировой карты напряжений» // Современная тектонофизика. Методы и результаты. Материалы Второй тектонофизической школы-семинара 17-21 октября 2011 г. М.: ИФЗ РАН, 2011. С. 130-138].

Kostrov B.V., 1975. Mechanics of Tectonic Earthquake Foci. Nauka, Moscow, 176 p. (in Russian) [Костров Б.В. Механика очага тектонического землетрясения. М.: Наука, 1975. 176 с.].

Kuchai O.A., Bushenkova N.A., 2009. Earthquake focal mechanisms in Central Asia. Fizicheskaya Mezomekhanika (Physical 
Mesomechanics) 12, 12-24 (in Russian) [Кучай О.А., Бушенкова Н.А. Механизмы очагов землетрясения Центральной Азии // Физическая мезомеханика. 2009. № 12. С. 12-24].

Kunin N.Ya., Ioganson L.I., Afonsky M.N., Abetov A.E., Doukaev S.Zh., 1988. Continental Basins of Central and Eastern Asia (Regularities of Deep Structure and Development). Publishing House of IPE AS USSR, Moscow, 168 p. (in Russian) [Кунин Н.Я., Иогансон Л.И., Афонский М.Н., Абетов А.Е., Даукаев С.Ж. Континентальные впадины Центральной и Восточной Азии (закономерности глубинного строения и развития). М.: Изд-во ИФЗ АН СССР, 1988.168 с.].

Laverov N.P., Aitmatov I.T., Bakirov A.B., Leonov Yu.G., Zeigarnik V.A., Makarov V.I., Novikov A.M., Shchelochkov G.G., 2006. Recent Geodynamics of Regions of Intracontinental Collisional Mountain Formation. Nauchny Mir, Moscow, 400 p. (in Russian) [Лаверов Н.П., Айтматов И.Т., Бакиров А.Б., Леонов Ю.Г., Зейгарник В.А., Макаров В.И., Новиков А.М., Щелочков Г.Г. Современная геодинамика областей внутриконтинентального коллизионного горообразования (Центральная Азия). М.: Научный мир, 2006. 400 с.].

Levi K.G., Sherman S.I., 2005. Top Issues of Recent Geodynamics of Central Asia. Publishing House of SB RAS, Novosibirsk, 294 p. (in Russian) [Леви К.Г., Шерман С.И. Актуальные вопросы современной геодинамики Центральной Азии. Новосибирск: Издательство СО РАН, 2005. 294 с.].

Logatchev N.A., Zorin Yu.A., 1987. Evidence and causes of two-stage development of the Baikal rift. Tectonophysics 143 (13), 225-234. http://dx.doi.org/10.1016/0040-1951(87)90092-8.

Makarov P.V., 2010. Self-organized criticality of deformation and prospects for fracture prediction. Physical Mesomechanics Journal 13, (5-6), 292-305. http://dx.doi.org/10.1016/j.physme.2010.11.010.

Michael A.J., 1984. Determination of stress from slip data: faults and folds. Journal of Geophysical Research: Solid Earth 89 (B13), 11517-11526. http://dx.doi.org/10.1029/JB089iB13p11517.

Milanovsky E.E., 1991. Main Stages of Rifting in the Territory of China. Nedra, Moscow, 148 р. (in Russian) [Милановский E.E. Основные этапы рифтогенеза на территории Китая. М.: Недра, 1991. 148 с.].

Mogi K., 1964. Deformation and fracture of rocks under confining pressure (1): compression test on dry rock sample. Bulletin of the Earthquake Research Institute, University of Tokyo 42 (3), 491-514.

Molnar P., Tapponnier P., 1975. Cenozoic tectonics of Asia: effects of continental collision. Science 189 (4201), 419-426. http://dx.doi.org/10.1126/science.189.4201.419.

Molnar P., Tapponnier P., 1978. Active tectonics of Tibet. Journal of Geophysical Research: Solid Earth 83 (B1), $5361-$ 5375. http://dx.doi.org/10.1029/JB083iB11p05361.

Mostryukov A.O., Petrov V.A., 1994. Catalogues of Earthquake Focal Mechanisms, 1964-1990. Materials from the World Data Centre. IPE RAS, Moscow, 87 p. (in Russian) [Мострюков А.О., Петров В.А. Каталог механизмов очагов землетрясений, 1964-1990 гг. Материалы мирового центра данных. М.: ИФЗ РАН, 1994. 87 с.].

Parfenov V.D., 1984. On the method of tectonophysical analysis of geological structures. Geotectonika 1, 60-72 (in Russian) [Парфенов В.Д. К методике тектонофизического анализа геологических структур // Геотектоника. 1984. № 1. С. 60-72].

Pavlov V.M., Abubakirov I.R., 2012. Algorithm for calculation of seismic moment tensor of strong earthquakes using regional broadband seismograms of body waves. Bulletin of Kamchatka regional association «Educational-scientific center». Earth sciences 2 (20), 149-158.

Petrov V.A., Anfu N., Smirnov V.B., Mostryukov A.O., Zhixiong L., Ponomarev A.V., Zaisen J., Xuhui S., 2008. Field of tectonic stresses from focal mechanisms of earthquakes and recent crustal movements from GPS measurements in China. Izvestiya, Physics of the Solid Earth 44 (10), 846-856. http://dx.doi.org/10.1134/S1069351308100121.

Petrov V.A., Mostrukov A.O., Lykov V.I., 1994. The recent field of tectonic stresses over territory of China Journal of Earthquake Prediction Research 3 (4), 509-527.

Pogrebnoi V.N., Sabitova T.M., 2001. Manifestation of the Tibet plume structure and seismicity of High Asia in regional geophysical fields. Russian Geology and Geophysics 42 (10), 1532-1542.

Rebetsky Yu.L., 1994. Reconstruction of relative values of components of total tensors of tectonic stresses. In: Abstracts of reports at the 1st International workshop on stresses in the lithosphere. IGiRGI Publishing House, Moscow, p. 146-147 (in Russian) [Ребецкий Ю.Л. Реконструкция относительных величин компонент полного тензора тектонических напряжений // Тезисы докладов первого международного семинара: Напряжения в литосфере (глобальные, региональные, локальные). М.: Издательство ИГиРГИ, 1994. С. 146-147].

Rebetsky Yu.L., 1996. Stress-monitoring: Issues of reconstruction methods of tectonic stresses and seismotectonic deformations. Journal of earthquake prediction research 5 (4), 557-573.

Rebetsky Yu.L., 1997. Paragenesises of quasiplastic deformation of fractured mediums. In: Proceedings of meeting on structural paragenesises and their ensembles. GEOS, Moscow, p. 144-146 (in Russian) [Ребецкий Ю.Л. Парагенезы квазипластического деформирования трещиноватых сред // Материалы совещания “Структурные парагенезы и их ансамбли”. М.: ГЕОС, 1997. С. 144-146].

Rebetsky Yu.L., 1999. Methods for Reconstructing Tectonic Stresses and Seismotectonic Deformations Based on the Modern Theory of Plasticity. Doklady Earth Sciences 365 (3), 370-373. 
Rebetsky Yu.L., 2003. Development of the method of cataclastic analysis of shear fractures for tectonic stress estimation. Doklady Earth Sciences 388 (1), 72-76.

Rebetsky Yu.L., 2005. Estimation of relative values of tensions as a second stage of reconstruction according to the data on rupture dislocations. Geophysical Journal 27 (1), 39-54.

Rebetsky Yu.L., 2007a. Tectonic Stresses and Strength of Rock Massifs. Akademkniga, Moscow, 406 p. (in Russian) [Ребецкий Ю.Л. Тектонические напряжения и прочность горных массивов. М.: Академкнига, 2007а. 406 с.].

Rebetsky Yu.L., 2007b. Tectonic stresses and areas of occurrence of earthquake triggering mechanism. Fizicheskaya Mezomekhanika (Physical Mesomechanics) 1 (10), 25-37 (in Russian) [Ребецкий Ю.Л. Тектонические напряжения и области триггерного механизма возникновения землетрясений // Физическая мезомеханика. 2007b. Т. 1. № 10. С. 25-37].

Rebetsky Yu.L., 2007c. Condition and problems of theories of earthquakes prediction. Analysis of bases from position of appointed approach. Geophysical Journal 29 (4), 92-110.

Rebetsky Yu.L., 2007d. New data on natural strains within the area of preparation for strong earthquake. The model of the earthquake source. Geophysical journal 29 (6), 92-110.

Rebetsky Yu.L., 2007e. Stressed state corresponding to the formation of large-scale brittle failure of rocks. Doklady Earth Sciences 417 (8), 1216-1220. http://dx.doi.org/10.1134/S1028334X07080181.

Rebetsky Yu.L., 2009a. The third and the fourth stages of strains reconstruction in the method of cataclastic analysis of shift ruptures. Geophysical Journal 31 (2), 93-106.

Rebetsky Yu.L., 2009b. Estimation of stress values in the method of Cataclastic analysis of shear fractures. Doklady Earth Sciences 428 (7), 1202-1207. http://dx.doi.org/10.1134/S1028334X09070368.

Rebetsky Yu.L., 2012a. Achievements of tectonophysic researches in Russia: perspective tectonophysic problems. Comptes Rendus Geoscience 344 (3-4), 116-124. http://dx.doi.org/10.1016/j.crte.2011.12.007.

Rebetsky Yu.L., 2012b. On a new form of instability of continental crust. In: Sedimentary basins and geological assumptions for forecasting of new oil and gas promising facilities. Proceedings of the XLIV tectonic meeting. GEOS, Moscow, Vol. II, p. 355-359 (in Russian) [Ребецкий Ю.Л. Об одной новой форме неустойчивости континентальной коры // Осадочные бассейны и геологические предпосылки прогноза новых объектов, перспективных на нефть и газ. Материалы XLIV тектонического совещания. М.: ГЕОС, 2012b. T. II. С. 355-359].

Rebetsky Yu.L., Kuchay O.A., Marinin A.V. 2013. Stress state and deformation of the Earth's crust in the Altai-Sayan mountain region. Russian Geology Geophysics 54 (2), 206-222. http://dx.doi.org/10.1016/j.rgg.2013.01.011.

Rebetsky Yu.L., Marinin A.V., 2006a. Stressed state of the Earth's crust in the western region of the Sunda subduction zone before the Sumatra-Andaman earthquake on December 26, 2004. Doklady Earth Sciences 407 (2), 321-325.

Rebetsky Yu.L., Marinin A.V., 2006b. Preseismic stress field before the Sumatra-Andaman earthquake of 26.12.2004: a model of Metastable state of Rocks. Russian Geology and Geophysics 47 (11), 1192-1206.

Rebetsky Yu.L., Mikhailova A.V, Rosanova G.V, Fursova E.V., 1997. Stress-monitoring: The modern field of regional stresses in South-East Asia and Oceania. Principles of quasiplastic deforming of fractured media. Journal of Earthquake Prediction Research 6 (1), 11-36.

Rebetsky Yu.L., Pogorelov V.V., 2013. Tectonophysical model of loading mechanism and evolution of stress-and-strain state of the lithosphere in mountainous folded regions. In: Geological history, potential mechanisms and problem of formation of basins in continental lithosphere provinces. Proceedings of the XLV Tectonic Meeting. GEOS, Moscow, Vol. II, p. 181-185 (in Russian) [Ребецкий Ю.Л., Погорелов В.В. Тектонофизическая модель механизма нагружения и эволюции напряженно-деформированного состояния литосферы континентальных горно-складчатых областей // Геологическая история, возможные механизмы и проблема формирования впадин с субокеанической и аномально тонкой корой в провинциях с континентальной литосферой. Материалы XLV тектонического совещания. М.: Издательство ГЕОС, 2013. Т. ІІ. С. 181-185].

Rebetsky Yu.L., Sycheva N.A., Kuchay O.A., Tatevossian R.E., 2012. Development of inversion methods on fault slip data. Stress state in orogenes of the Central Asia. Tectonophysics 581, 114-131. http://dx.doi.org/10.1016/j.tecto.2012.09.027.

Rebetsky Yu.L., Tatevossian R.E., 2013. Rupture propagation in strong earthquake sources and tectonic stress field. Bulletin de la Société Géologique de France 184 (4-5), 335-346. http://dx.doi.org/10.2113/gssgfbull.184.4-5.335.

Riznichenko Yu.V., 1968. An energy model of seismic regime. Izvestia AN SSSR. Seriya Fizika Zemli (Izvestia AN SSSR. Earth’s Sciences Series) 5, 3-9 (in Russian) [Ризниченко Ю.В. Энергетическая модель сейсмического режима // Известия АН СССР. Серия Физика Земли. 1968. № 5. С. 3-9].

Seminskii K.Zh., 2008. Hierarchy in the zone-block lithospheric structure of Central and Eastern Asia. Russian Geology and Geophysics 49 (10), 771-779. http://dx.doi.org/10.1016/j.rgg.2007.11.017.

Sherman S.I., Dneprovsky Yu.I., 1989. Stress Fields of the Earth’s Crust. Publishing House of SB RAS, Novosibirsk, 155 p. (in Russian) [Шерман С.И., Днепровский Ю.И. Поля напряжений земной коры. Новосибирск: Изд-во СО АН CCCP, 1989. 155 c.].

Sherman S.I., Lunina O.V., 2001.A New Map Representing Stressed State of the Upper Part of the Earth’s Lithosphere. Doklady Earth Sciences 379 (5), 553-555. 
Stavrogin A.N., Protosenya A.G., 1992. Mechanics of Rock Deformation and Destruction. Nedra, Moscow, 223 p. (in Russian) [Ставрогин А.Н., Протосеня А.Г. Механика деформирования и разрушения горных пород. М.: Недра, 1992. 223 c.].

Stuwe K., 2007. Geodynamics of the Lithosphere. An Introduction. 2nd Edition. Springer, Berlin - Heidelberg, 493 p.

Trifonov V.G., Soboleva O.V., Trifonov P.V., Vostrikov G.A., 2002. Recent Geodynamics of the Alpine-Himalayan Collisional Belt. GEOS, Moscow, 224 p. (in Russian) [Трифонов В.Г., Соболева О.В., Трифонов Р.В., Востриков Г.А. Современная геодинамика Альпийско-Гималайского коллизионного пояса. М.: ГЕОС, 2002. 224 с.].

Vvedenskaya A.V., 1969. Studies of Stresses and Fractures in Earthquake Foci by the Theory of Dislocations. Nauka, Moscow, 136 p. (in Russian) [Введенская А.В. Исследования напряжений и разрывов в очагах землетрясений при помощи теории дислокаций. М.: Наука, 1969. 136 с.].

Wickens A.J., Hodgson J.H., 1967. Computer re-evaluation of earthquake mechanism solutions 1922-1962. In: Publications of the dominion observatory Ottawa. Vol. XXXIII, No 1, 560 p.

Yunga S.L., 1990. Methods and Results of Studies of Seismotectonic Deformations. Nauka, Moscow, 190 p. (in Russian) [Юнга С.Л. Методы и результаты изучения сейсмотектонических деформаций. М.: Наука, 1990. 190 с.].

Zhonghuai Xu., Suyun W., Yurui H., Ajia G., 1992. Tectonic stress field of China inferred from a large number of small earthquakes. Journal of Geophysical Research 97 (B8), 11867-11878. http://dx.doi.org/10.1029/91JB00355.

Zobak M.L., 1992. First- and second order pattern of stress in the lithosphere: The Word stress map project. Journal of Geophysical Research 97 (B8), 11703-11728. http://dx.doi.org/10.1029/92JB00132.

Zubovich A.V., Makarov V.I., Kuzikov S.I., Mosienko O.I., Shchelochkov G.G., 2007. Intracontinental Mountain Building in Central Asia As Inferred from Satellite Geodetic Data. Geotectonics 41 (1), 13-25. http://dx.doi.org/10.1134/S0016852 107010037.
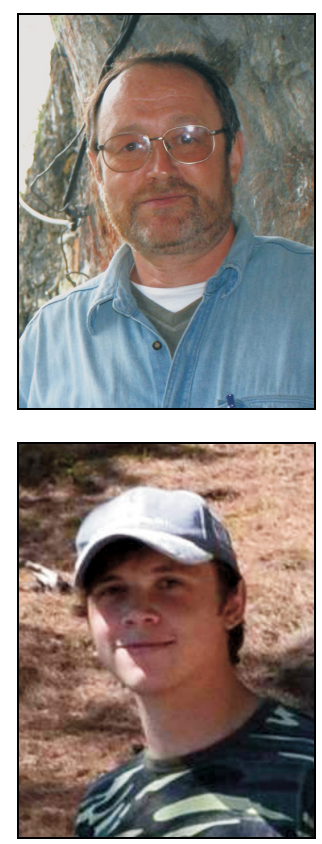

Алексеев Роман Сергеевич, инженер лаборатории тектонофизики им. М.В. Гзовского, студент 6-го курса Институт физики Земли им. О.Ю. Шмидта РАН

123995, ГСП-5, Москва Д-242, ул. Большая Грузинская, 10, Россия

Московский государственный университет им. М.В. Ломоносова, физический факультет

119991, ГСП-2, Москва, Ленинские горы, д. 1, строение 2

Alekseev, Roman S., engineer of M.V. Gzovsky Laboratory of Tectonophysics, student of 6th year Schmidt Institute of Physics of the Earth, RAS

10 Bol'shaya Gruzinskaya street, Moscow D-242 123995, GSP-5, Russia

Lomonosov Moscow State University, Faculty of Physics

1 Leninskie Gory, building 2, Moscow 119991, GSP-2, Russia 